\title{
Fotografias de cegos: olhar além da visão
}

\author{
Blind photographs: looking beyond vision
}

\section{Las fotografías de ciegos: una mirada para más allá de la visión}

\author{
iD (9) Olivia von der Weid \\ Universidade Federal Fluminense, Niterói, Rio de Janeiro, Brasil \\ oliviaweid@id.uff.br
}

Resumo: Inquietações a respeito do papel da imagem na sociedade atual e a observação de sua preponderância nas relações entre os indivíduos são o ponto de partida para uma reflexão sobre a relação de pessoas cegas com a fotografia. Como uma imagem gerada por um fotógrafo cego se insere no mundo imagético contemporâneo? Neste artigo analiso o catálogo da exposição "Sight Unseen", que exibiu o trabalho de doze fotógrafos cegos. Procuro compreender como as imagens são apresentadas e os argumentos envolvidos na contextualização do trabalho artístico. Avalio de que forma as obras mobilizam as noções de visão e de olhar que permeiam o universo da imagem e que desestabilizações são levantadas em torno destes conceitos. Finalmente, reflito sobre o que as imagens geradas por fotógrafos cegos podem nos ensinar sobre a visualidade e a variabilidade das formas de ver.

Palavras-chave: Cegueira. Sentidos. Percepção. Imagem. Fotografia.

Abstract: Concerns about the role of the image in today's society and the observation of its preponderance in the relationships between individuals are the starting point for a reflection on the relationship of blind people with photography. How does an image generated by a blind photographer fits into the contemporary imagery world? 
In this article I analyze the catalog of the exhibition "Sight Unseen", which presented the work of twelve blind photographers. I try to understand how the images of these photographers are presented and the arguments involved in the contextualization of their artistic work. I evaluate how their works mobilize the notions of sight and gaze that permeate the universe of the image and what kind of destabilization are raised around these concepts. Finally, I reflect on what the images generated by blind photographers teach us about visuality and our ways of seeing.

Keywords: Blindness. Senses. Perception. Image. Photography.

Resumen: Las inquietudes sobre el papel de la imagen en la sociedad actual y la observación de su preponderancia en las relaciones entre individuos son el punto de partida para una reflexión sobre la relación de las personas ciegas con la fotografía. ¿Cómo se inserta una imagen generada por un fotógrafo ciego en el mundo de las imágenes contemporáneas? En este artículo, analizo el catálogo de la exposición "Sight Unseen", que presentó el trabajo de doce fotógrafos ciegos. Trato de entender cómo se presentan las imágenes y los argumentos involucrados en la contextualización de su obra de arte. Además, evalúo cómo las obras movilizan las nociones de visión y mirada que impregnan el universo de la imagen y qué desestabilizaciones se generan en torno a estos conceptos. Finalmente, reflexiono sobre qué las imágenes generadas por los fotógrafos ciegos nos pueden enseñar sobre la visualidad y la variabilidad de las formas de ver.

Palabras-clave: Ceguera. Sentido. Percepción. Imagen. Fotografía.

Data de recebimento do artigo: 02/07/2018

Data de aprovação do artigo: 12/10/2019 


\section{Introdução}

Que futuro estará reservado à imaginação individual nessa que se convencionou chamar a "civilização da imagem"? O poder de evocar imagens in absentia continuará a desenvolver-se numa humanidade cada vez mais inundada pelo dilúvio das imagens pré-fabricadas? (...) Hoje somos bombardeados por uma tal quantidade de imagens a ponto de não podermos distinguir mais a experiência direta daquilo que vimos há poucos segundos na televisão. Em nossa memória se depositam, por estratos sucessivos, mil estilhaços de imagens, semelhantes a um depósito de lixo, onde é cada vez menos provável que uma delas adquira relevo. Se incluí a visibilidade em minha lista de valores a preservar foi para advertir que estamos correndo o perigo de perder uma faculdade humana fundamental: a capacidade de pôr em foco visões de olhos fechados (Calvino, 1997, p. 107)

O maior acesso a câmeras de qualidade, a disseminação de cursos presenciais ou virtuais que ensinam técnicas fotográficas, a multiplicação de fotógrafos amadores levam ao questionamento dos significados das imagens produzidas e da intenção de sua produção nos dias atuais. Vivemos mergulhados em instantâneas apresentações de si divulgadas por meio de dispositivos virtuais de todo tipo. Sua qualidade estaria no primor da técnica ou naquilo que punge da foto, na imagem que lança o desejo para além do que ela dá a ver (BARTHES, 2008)?

A discussão se a fotografia pode ser considerada arte data dos primórdios de sua invenção e, em sua clássica reflexão, Benjamin (1975) busca identificar a diferença entre uma obra de arte original e suas reproduções por meio da noção de "aura". A multiplicação da cópia, pela introdução dos meios técnicos de reprodução, incorre na perda da aura, aquele caráter único da obra que remete a uma realidade longínqua, por mais próxima que esteja. A foto- 
grafia empurraria o valor de culto para segundo plano, substituído pelo valor de exibição.

A cegueira me aparece como objeto de pesquisa em um momento muito particular de busca por um tema que expressasse meus interesses ou talvez meu próprio "olhar" para o mundo. Há alguns anos vinha investindo em outra forma de ver o mundo e representá-lo: a fotografia. Foi justamente em uma aula de fotografia que comecei a espreitar o tema da cegueira. Mais especificamente as afetações dessa experiência na percepção, na imagem de si e do mundo de quem não enxerga.

A motivação para a realização deste artigo parte de inquietações pessoais a respeito do papel da imagem na sociedade atual e da observação de sua preponderância nas relações dos indivíduos com o mundo e com os outros. Os questionamentos levaram a refletir sobre a relação de pessoas cegas com a fotografia e como uma imagem produzida por um fotógrafo cego se insere no mundo visual contemporâneo. Qual o repertório imagético destes fotógrafos e em que medida as suas imagens são capazes de transmitir representações para além da visualidade? Utilizo como motor das reflexões o catálogo da exposição "Sight Unseen: International Photography by Blind Artists". A curadoria é de Douglas McCulloh (2009) e foi realizada no California Museum of Photography. A exposição apresenta o trabalho de doze fotógrafos cegos, provenientes dos seguintes países: Estados Unidos, México, França e Escócia. No texto de apresentação, o curador sugere que a exposição foi a primeira grande exibição da obra de fotógrafos cegos mundialmente reconhecidos, e sua curadoria explorou a ideia central de que tais fotógrafos poderiam enxergar de modos que pessoas com visão não poderiam. Conceitualmente, produz-se, assim, uma inversão: por não enxergarem, "os fotógrafos cegos possuiriam a visão mais clara do planeta" (MCCULLOH, 2009, p. 2, tradução livre).

Douglas McCulloh estrutura as imagens dos fotógrafos da exposição em torno de três grupos, de acordo com o que os motiva a fotografar. Um deles são os artistas que constroem, mantém e aprimoram galerias internas de imagens, trazendo suas visões in- 
teriores para o mundo dos que enxergam. O segundo grupo estaria engajado no que o curador chamou, resgatando Marcel Duchamp, de "fotografia da não-retina". Um terceiro grupo seria formado pelos fotógrafos que são legalmente cegos, mas que ainda mantém um percentual de baixíssima visão. São artistas que fotografam para ver, com o auxílio de dispositivos tecnológicos, entre eles a câmera. Para além dos três grupos conceituais de imagens geradas por estes fotógrafos, sua prática é também apresentada como política. Apertar o botão da câmera é um ato de reivindicação do mundo visual, que força uma reavaliação de certos estereótipos estabelecidos sobre a cegueira.

No que se segue, procuro compreender como as imagens são apresentadas nos três grupos, os elementos que distinguem a produção e contextualização de seu trabalho. Avalio de que forma as obras mobilizam as noções de visão e de olhar que permeiam o universo da imagem e que desestabilizações são levantadas em torno desses conceitos. Finalmente, reflito sobre o que as imagens geradas por fotógrafos cegos podem nos ensinar sobre a visualidade e a variabilidade das formas de ver. A proposta não é tanto desenvolver uma reflexão sobre a estética fotográfica, mas sim proceder uma análise do processo perceptivo e cognitivo de formação de representações na cegueira, tomando como base as imagens geradas por fotógrafos cegos. Trazendo as fotografias como material analítico, procuro relacionar os históricos distintos de cegueira com as imagens geradas, desenvolvendo uma reflexão sobre a implicação ativa do corpo para aquilo que, cegos ou não, somos capazes de olhar e registrar.

\section{Imagens internas - visão conceitual}

Eu fotografo o que imagino

Evgen Bavcar

Douglas McCulloh abre o catálogo apresentando a primeira grande exposição em museu sobre um assunto "repleto de para- 
Fotografias de cegos: olhar além da visão Olivia von der Weid

doxo e revelação" (MCCULLOH, 2009, p. 2, tradução livre). A argumentação do curador sobre as fotografias tiradas por fotógrafos cegos remete a contrastes que podem se articular de forma paradoxal, expressos nos pares ver e não ver, dentro e fora, convencional e inesperado, limitação e liberdade. Em diversos momentos menciona-se o mundo da fotografia ${ }^{1}$ mais amplo, as imagens produzidas neste mundo, suas regras, convenções e recursos, em comparação ao processo criativo de fotógrafos cegos e às imagens geradas por eles.

Um dos grupos de fotógrafos da exposição, cujo expoente principal estaria em Evgen Bavcar, faz uso da câmera para trazer suas visões internas para o mundo dos que enxergam. De acordo com McCulloh (2009), a fotografia, para estes artistas, seria o processo de criar manifestações físicas de algo que já existe internamente como ideia. Suas imagens são primeiramente visualizações para depois se transformarem em fotografias. Bavcar, no catálogo da exposição, comenta: “o que eu quero dizer com desejo por imagem é que quando nós imaginamos coisas, nós existimos. Eu não posso pertencer a este mundo se não posso imaginá-lo do meu próprio jeito. Quando uma pessoa cega diz 'eu imagino', significa que ela também possui uma representação interior de realidades externas" (MCCULLOH, 2009, p. 3, tradução livre). Na imagem “Um sonho de movimento" (Figura 1 - "A dream of motion"), temos uma imagem em preto e branco, onde se vê uma bicicleta contra um fundo preto. Na lateral superior da bicicleta vemos quatro pássaros de papel. Na lateral inferior, próximo à roda frontal, dois outros pássaros de papel². É como se os pássaros estivessem voando ao lado da bicicleta que, embora não esteja sendo pilotada por ninguém, também parece estar em movimento.

\footnotetext{
1 Utilizo o conceito de mundo da fotografia baseada no conceito de "mundo da arte", descrito por Becker (2008) como uma rede de pessoas cuja atividade cooperativa, organizada através de seu conhecimento conjunto dos meios convencionais de fazer coisas, produz os tipos de trabalhos artísticos que caracterizam o mundo da arte.

$2 \mathrm{~A}$ foto foi feita usando-se a técnica conhecida por light painting (Pintar com a luz).
} 
Figura 1. "A dream of motion", Evgen Bavcar

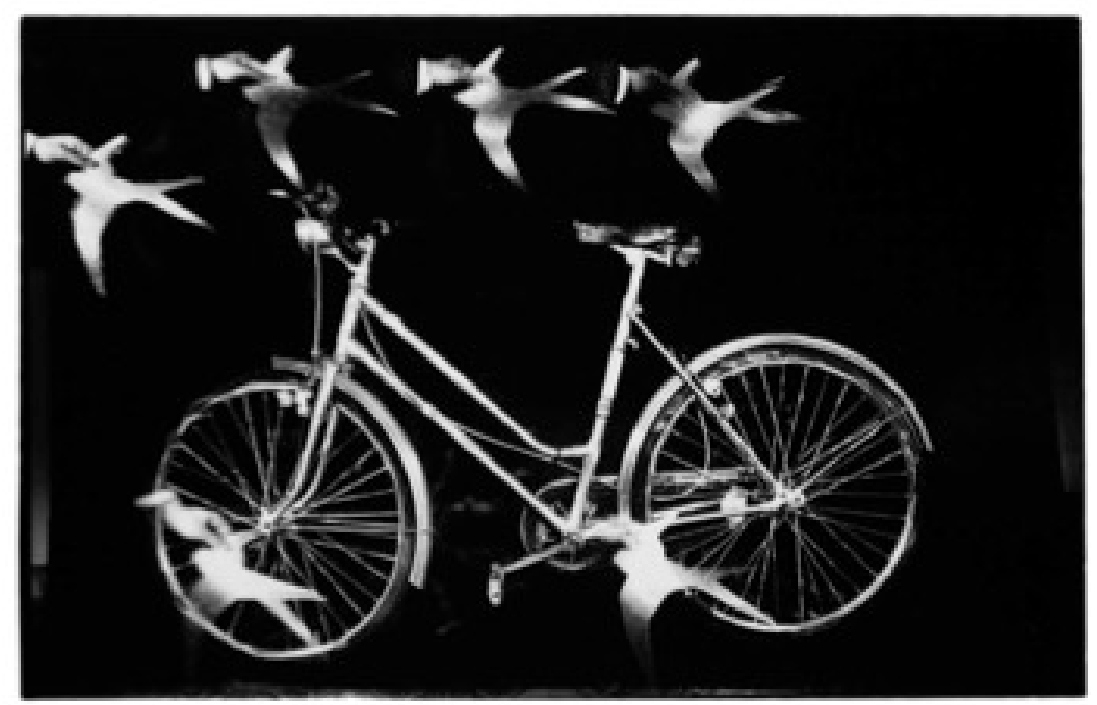

Fonte: Catálogo da exposição Sight Unseen (2009), p. 15.

As imagens originadas por este grupo de fotógrafos expressam materialmente, por meio das fotos que criam, o significado de imaginação, no sentido primeiro dado pelo dicionário3: faculdade com que o espírito cria imagens, representações, fantasias. Mais distantes da cópia, de um modelo exato do real, estariam mais próximas da ideia, do conceito ou uma criação mental. O ponto de partida pode vir de motivações diversas, como recordações e memórias, no caso de Alice Wingwall; ou o inumano, no caso de Kurt Weston que, com seus autorretratos, procurava dar visibilidade ao estigma de ser cego, homossexual e pessoa com HIV. Na imagem "Máscara" (Figura 2 - "Mask"), vemos o rosto do artista de perfil, amassado contra o que parece ser uma superfície, embora esta não seja visível na foto. Seu rosto está envelhecido, a pele bastante enrugada, aparece o bigode branco, o nariz fino, o seu olho está fechado e bastante afundado no interior da cavidade facial. Sua obra é enquadrada no que o curador chamou de mundo do grotesco. $\mathrm{O}$ artista diz que, em suas fotografias, busca transformar a si próprio em um objeto estigmatizado, a fim de forçar as pessoas a repensarem seus limiares de normalidade e anormalidade. $O$ fo-

3 http://www.priberam.pt/dlpo/default.aspx?pal=imaginação. Acesso em 19 de junho de 2019. 
tógrafo usa um escâner como câmera o que, para o curador, traz às suas fotografias um ar de hiper-realismo e imediaticidade.

Figura 2. “Mask", Kurt Weston

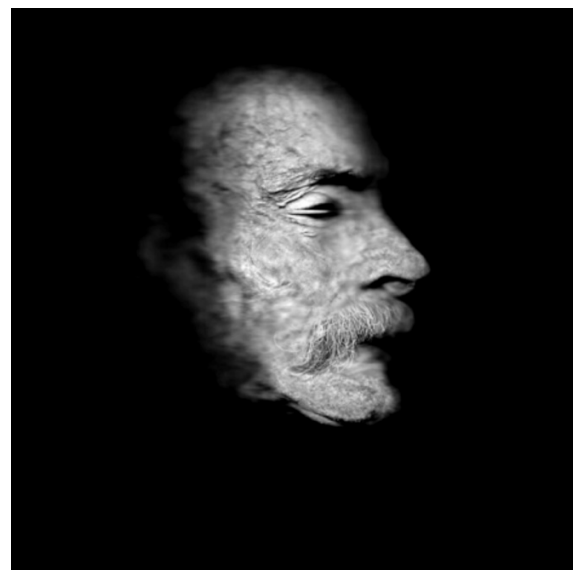

Fonte: Catálogo da exposição Sight Unseen (2009), p. 110.

Pete Eckert, outro artista da exposição que se aproxima deste grupo, diz que "mesmo sem entradas, ou especialmente sem entradas, o cérebro continua criando imagens. Sou uma pessoa muito visual, eu apenas não posso ver" (MCCULLOH, 2009, p. 3, tradução livre). As imagens são criadas a partir de um histórico particular de experiências e interações dos corpos no mundo. Nossas vivências geram um estoque sensorial que é constantemente acionado para informar as novas experiências. Não tendo mais o sentido visual, as pessoas que se tornam cegas continuam se relacionando com o seu estoque imagético, ou seja, continuam capazes de gerar internamente visualizações. O resultado imagético final, entretanto, nunca é uma representação exata de uma concepção mental. O artista revela: "eu estruturo meus cliques da mesma maneira. Os visualizo e então adapto. Presumo que vai ser três quartos do jeito que planejei e um quarto do que acontece" (MCCULLOH, 2009, p. 28, tradução livre). Na imagem "Estações" (Figura 3 - "Stations"), temos um corredor com o chão verde e a parede lateral direita ladriIhada, no interior de uma construção que aparenta ser uma igreja, em função de um quadro com formas religiosas que se ergue ao fundo. No primeiro plano, uma figura cujos contornos feitos de 
Fotografias de cegos: olhar além da visão

luz parecem dançar pelo corredor. Para produzir suas imagens, ele também utiliza Light Painting: primeiro monta todo o cenário, escurece o ambiente e trabalha com a câmera em um tripé. Usa tempos longos de exposição, durante o qual ele vagueia pelo espaço e pinta sua imagem com alguma fonte de luz - flashes, velas, lanternas, laser.

Figura 3. "Stations", Pete Eckert

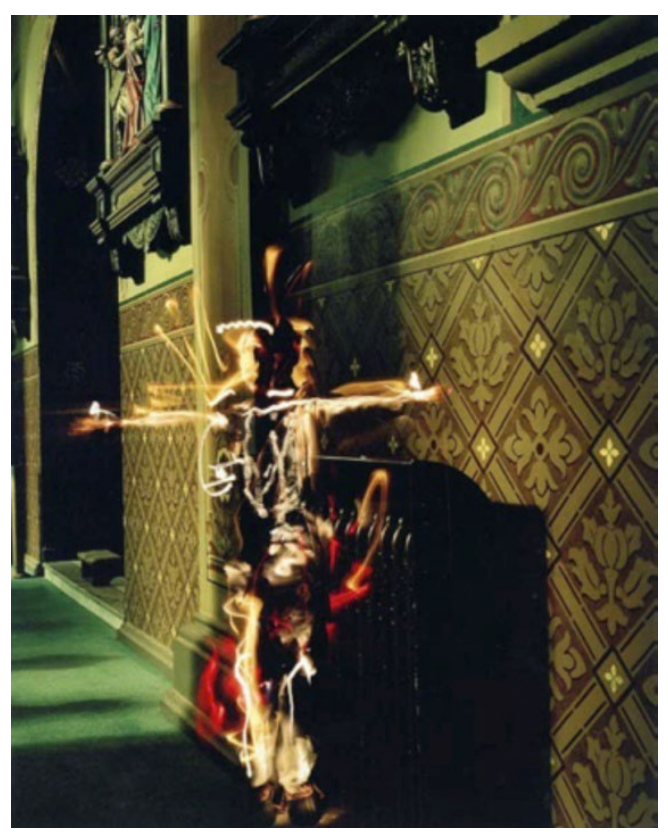

Fonte: Catálogo da exposição Sight Unseen (2009), p. 31.

As imagens geradas neste primeiro grupo são feitas com o uso de técnicas fotográficas, com o auxílio de pontos de luz e objetos, algumas vezes tempo de exposição prolongado e outras pessoas ajudando. Para produzi-las, eles dispõem dos "vínculos cooperativos", identificados por Becker (2008) no mundo da arte como o centro de uma rede de pessoas que colaboram e cujos trabalhos são essenciais para o resultado final.

A combinação de duas ideias encontradas nos depoimentos anteriores, a concepção mental da imagem antes da sua realização e o não controle absoluto do resultado final, o espaço aberto do inesperado, nos remetem à noção de criação artística desen- 
volvida por Simmel (1996) a respeito das pinturas de Rembrandt. Para se reportar ao processo criativo, o autor usa a imagem de um germe, ou semente, e sua maturação, processo que o converterá em um ser vivo concluído. A semente não contém o ser vivo em tamanho diminuto, mas sim estabelece uma relação puramente funcional, já que contém, exclusivamente, as energias potenciais que o dirigem a esta relação. Uma unidade que existe antes no criador, até se transformar em forma. A forma final que assume, entretanto, não será o espelho da semente, mas o resultado de seu desenvolvimento.

O processo de criação das fotos, o discurso do curador da exposição e dos próprios artistas quando falam sobre sua criação apresentam as imagens com uma estética específica: um trabalho inerentemente conceitual, que daria forma a uma representação interna. Bavcar (1994) diz que o aparelho fotográfico seria para ele um acessório técnico com o qual busca exprimir sua situação existencial. Procura fazer existir uma imagem mental, convertendo-a em película. Comentando a força e o valor da fotografia, Soulages (2017) fala da lacuna infinita que pode separar a obra inicial e a obra de chegada, ou seja, a foto criada. No trabalho do primeiro grupo de artistas temos uma fotografia que potencializa um arsenal visual experimentado no passado, mas que ganha duração no presente. Com uma intensidade capaz de gerar ficções ou criações internas, que não temos como medir o quanto se aproximam ou se afastam de sua origem, uma vez que só existem virtualmente. Sua realidade como foto depende aqui não somente da arte, mas da memória.

Mondzain (2010) sublinha que é o destino de cada sujeito humano se inscrever no mundo por meio de operações simbólicas e, portanto, por meio da produção de signos que fundamentam sua relação com a fala. É a operação de produção de imagens que torna a inscrição possível. Nós não vemos o mundo porque temos olhos. Nossos olhos são abertos por nossa habilidade de produzir imagens, por nossa capacidade de imaginar. Segundo a autora, é por causa dessa capacidade que precisamos da visão para ser- 
mos aptos a falar e é também por causa dela que os cegos podem falar, uma vez que sua capacidade para imaginar está intacta. Os trabalhos deste grupo de fotógrafos cegos revelam os modos de produção de imagens a partir de um histórico particular de relação entre visualidade e cegueira. Se o visual é o aspecto privilegiado nos processos de simbolização e representação, as imagens fabricadas por eles sugerem novas formas de significar e apresentar tal acervo visual que não tomam a visão presente como ponto de partida ou referencial, ainda que seu resultado esteja referido a uma visualidade passada, a uma composição imaginada, e seja apresentado visualmente.

Para Bohme (1993), não podemos compreender o que faz de um trabalho uma obra de arte considerando apenas suas qualidades concretas, é preciso também levar em conta aquilo que a excede, um algo "a mais": sua aura ou "atmosfera". O excedente que conforma a atmosfera estética das fotografias do primeiro grupo está na sua imagem mental, a semente que os fotógrafos desejaram comunicar a um possível observador. Pelos seus depoimentos, percebe-se que são pessoas que perderam a visão, mas se relacionam internamente com a visualidade das imagens que um dia viram. Com a mediação do aparato fotográfico buscam mimetizar suas imagens mentais, trazendo visualidade a um acervo mnemônico que, embora não receba novos estímulos visuais, reorganiza fragmentos visíveis formando novos arranjos e composições. Gagnebin (1993) lembra que a atividade mimética não se reduz a uma imitação, é sempre mediação simbólica, semelhança que produz diferença, formando uma nova intensidade. Por meio da fotografia, eles experimentam e criam seus "outros", dando visualidade a imagens que os seus olhos já não captam.

\section{Corpo que percebe, sente e registra}

O segundo grupo de artistas faz uso da câmera para captar e representar o mundo, mas, sendo cegos, não o fazem pelos mes- 
mos estímulos de fotógrafos que enxergam. São fotografias que retratam o cotidiano, onde os elementos não-visuais que motivaram o registro estão presentes na cena. As fotos aparecem como resultados de um cheiro, um toque, a sensação do vento, as sonoridades do entorno. Através de sensações que captam com todo o corpo, conseguem perceber o ambiente, senti-lo e retratá-lo. Um dos fotógrafos deste grupo, Henry Butler, também pianista de blues, usa os sons para guiar seus cliques pelas ruas de Nova Orleans. Suas fotos são apresentadas como pistas auditivas, sugestões auriculares, capazes de retratar o estímulo que as guiaram. Na imagem "Sutiã de chaves" (Figura 4 - "Key bra"), Henry Butler fotografou em plano de detalhe o colo de uma mulher fantasiada, vestida com um sutiã e um colar coberto de chaves penduradas. Na imagem também se vê seus braços e suas duas mãos que apontam na direção dos seios e ela veste luvas marrons com chaves costuradas na ponta de cada dedo. Ela está na rua, pois na lateral direita aparece uma faixa de asfalto.

Figura 4. "Key bra”, Henry Butler

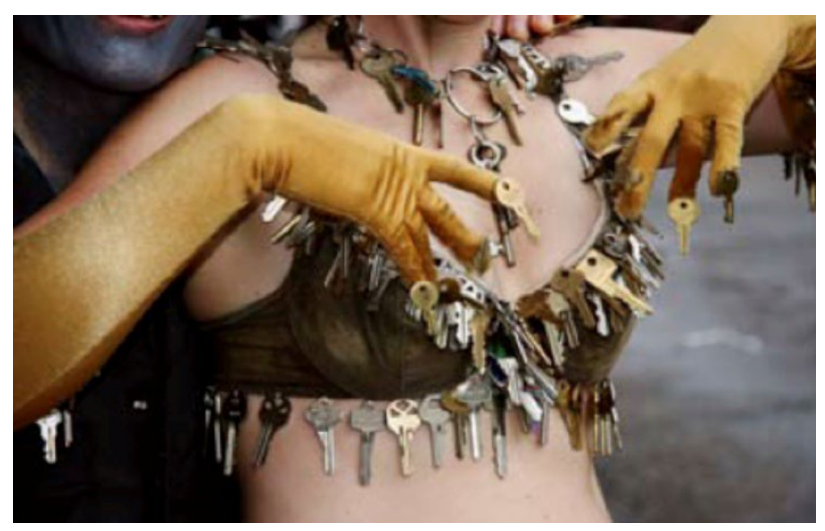

Fonte: Catálogo da exposição Sight Unseen (2009), p. 22.

A imagem "Miçangas e seios" (Figura 5 - "Beads and Boobs") foi também tirada em plano aproximado, ressaltando o colo de uma mulher que veste um top de lantejoulas verdes. Não vemos seu rosto, mas de sua cabeça descem cordões de miçangas douradas 
que, provavelmente, pendem de um acessório como um chapéu. Ela segura os cordões em sua mão esquerda que, embora também não apareça na cena, é sugerida pelo seu braço que está lateralmente aberto. Algumas penas vermelhas pendem do cordão e ao fundo se vê o muro verde de uma construção com janelas brancas fechadas, o que também indica o cenário da rua.

Figura 5. "Beads and Boobs", Henry Butler

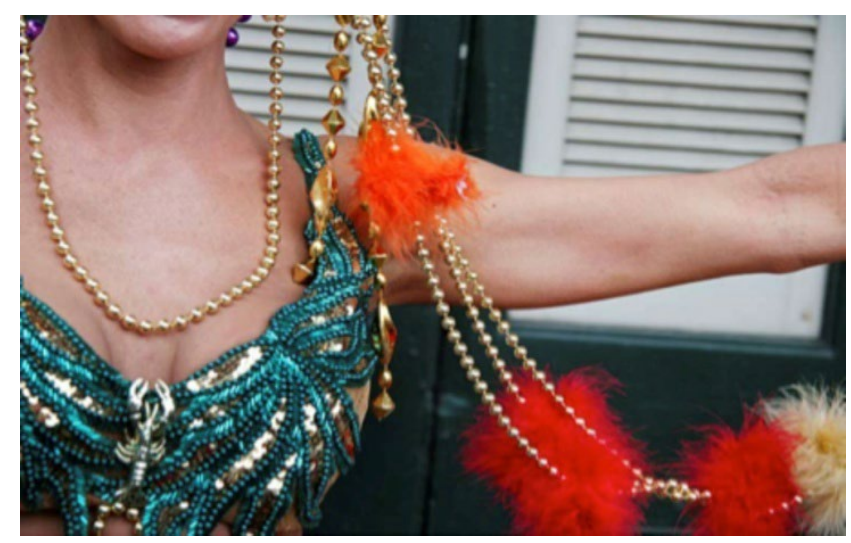

Fonte: Catálogo da exposição Sight Unseen (2009), p. 24.

Nas imagens é perceptível a motivação sonora para o clique pelo plano aproximado que ressalta os objetos, como as chaves e os cordões de miçangas, nos levando a imaginar o horizonte auditivo gerado pelo movimento dos corpos no ambiente fotografado. Outra qualidade de imagem sonora é retratada por Gerardo Nigenda. Na imagem seguinte temos um plano aberto que mostra uma rua com calçamento de pedra, desembocando em outra rua ao fundo. À direita da cena um mato alto sugere um cenário rural. No fundo da imagem, à esquerda, está o objeto da foto, um homem sentado em uma carroça puxada por um cavalo, que já está com a cabeça saindo do quadro. Eles estão passando em frente a uma construção cercada com um muro alto de pedra. O título da imagem diz: "A grandeza do som e a doçura do cheiro confundem, mas estimulam a visão" (Figura 6 - "The greatness of the sound and 
Fotografias de cegos: olhar além da visão

Olivia von der Weid

a sweet smell perplexes but stimulates the sight" - MCCULLOH, 2009, p. 68, tradução livre).

Figura 6. "The greatness of the sound and a sweet smell perplexes but stimulates the sight", Gerardo Nigenda

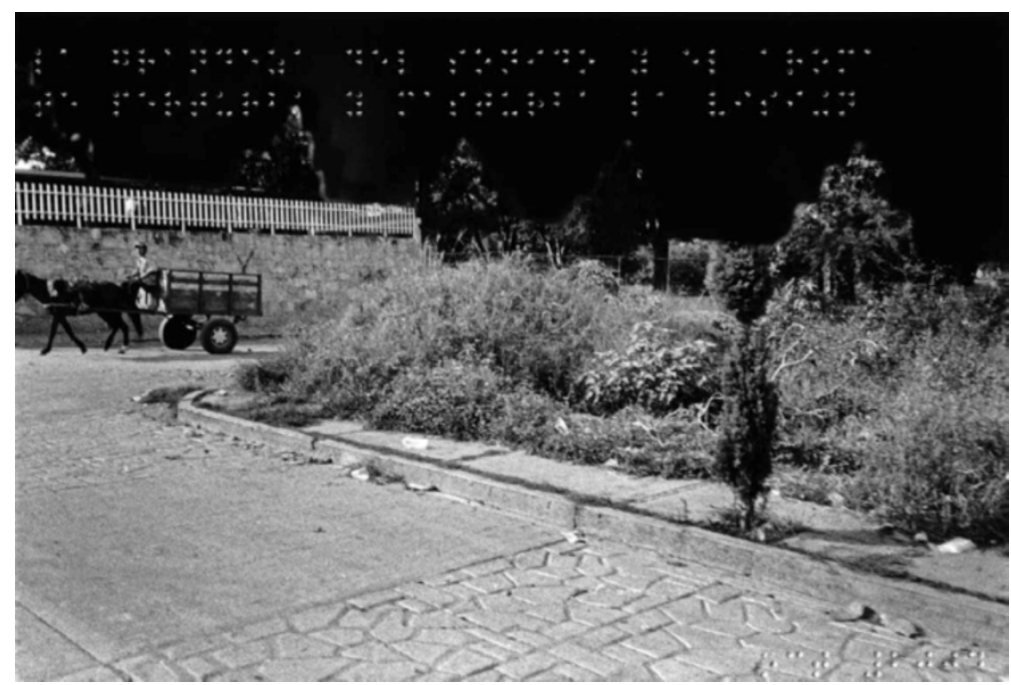

Fonte: Catálogo da exposição Sight Unseen (2009), p. 68.

Na fotografia de Gerardo Nigenda é quase possível, para o espectador, ouvir os ecos das patas do cavalo ressoando no muro alto, preenchendo a rua toda pelo caminho de pedras. Embora operando de forma distinta do sentido visual, os sons do ambiente também possibilitam a percepção espacial da distância. A relação dos objetos nos planos fotografados - em primeiríssimo plano, no caso das fotografias de Henry Butler, em plano aberto, com a câmera distante do objeto, na foto de Nigenda - nos leva a imaginar a intensidade, a qualidade e a altura destas distintas sonoridades no momento exato do clique. O referencial auditivo permite a pessoas cegas produzirem imagens que indicam a localização dos objetos em uma cena. Gera-se um registro que é tanto auditivo quanto espacial. Esta é uma propriedade da percepção sonora disponível a todas as pessoas que escutam, basta fechar os olhos por um momento e prestar atenção às qualidades dos sons que chegam do ambiente, suas fontes emissoras e distintas origens. 
Mas é claro que se consideramos, com Ingold (2010), que as bases neurológicas das competências humanas se estabelecem por meio do movimento e da ação guiados, as pessoas cegas provavelmente terão a habilidade de discriminação auditiva das distâncias espaciais muito mais finamente desenvolvida do que pessoas que enxergam, em função do uso que fazem da audição nas suas práticas cotidianas e em seus deslocamentos. Os traços acústicos são como timbres, sonoridades que também indicam a qualidade diferenciante dos objetos: o tilintar suave e próximo das chaves, o som seco do compasso da ferradura batendo num chão de pedra.

Outro referencial primordial na produção de imagens na cegueira é a percepção tátil. Diferente da visão ou da audição, o tato é uma percepção que não toma distância, mas que constrói o conhecimento parte por parte, imerso em proximidade, atento aos detalhes que se apreende com o corpo inteiro. Enquanto a visão é um sentido sintético, com um só olhar já se percebe todo o contexto de uma cena, a experiência perceptiva tátil é analítica, para se chegar ao todo é necessário percorrer cada parte, para então remontá-las em uma representação contextual mais abrangente. A percepção háptica tem, portanto, uma temporalidade própria e um caráter eminentemente sequencial (HATWELL, 2003). A superfície a ser tocada ou o objeto a ser percebido também precisam estar próximos ou afetar o corpo daquele que percebe, pois esta é uma percepção de contato. Na imagem "Um olhar aproximado" (Figura 7 - "A Close Up View"), temos uma fotografia tirada em primeiríssimo plano onde vemos a mão esquerda do fotógrafo que toca o rosto de uma estátua. Seus dedos pousam sobre o nariz, e a cabeça da estátua pende para o lado esquerdo. 
Figura 7. "A Close Up View”, Evgen Bavcar

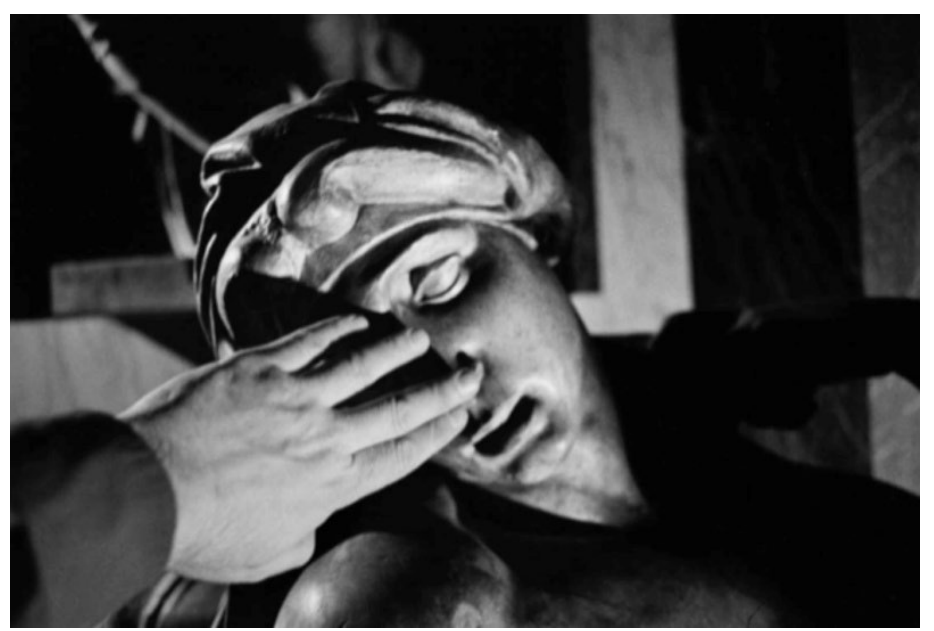

Fonte: Catálogo da exposição Sight Unseen (2009).

A fotografia tátil retrata não um olhar do olho, mas um olhar do sensível, um olhar do toque. Para Bavcar (2003), a cegueira desloca o olhar físico através do corpo inteiro, pois para uma pessoa cega, é todo o corpo que de alguma forma se torna órgão da vista já que qualquer parte do corpo pode olhar de perto um objeto que Ihe seja exterior. Uma característica comum da percepção tátil ativa é o engajamento das mãos, que tocam os objetos para os reconhecerem, transformando-os em imagens ou referências para uma ação em curso. O motivo fotografado muitas vezes está próximo de quem fotografa, à distância de um braço, ou mesmo o próprio toque aparece explicitado na foto. Na Figura 14, de Gerardo Nigenda (reproduzida mais adiante), também se vê o exercício deste olhar aproximado através da presença ativa do toque.

Outra possibilidade é uma imagem tátil passiva, ou uma imagem olfativa, em que o estímulo sensorial é recebido de forma não intencional pelo sujeito, quando nem mesmo é necessário se movimentar para ser afetado por ele. Na imagem "Funchos e sebes" (Figura 8 - "Fennel and Hedge"), de Rosita Mckenzie, vemos uma vegetação no plano mais próximo da câmera, envolta por uma cerca viva localizada no quadrante superior da imagem. A foto registra o movimento das folhas em primeiro plano, que nos permite 
presumir que uma brisa possa ter gerado o estímulo tátil passivo para a sua captação. No entanto, o próprio título da imagem, ou mesmo o possível reconhecimento pelo espectador das espécies vegetais ali registradas, também sugere uma segunda motivação sensorial passiva para a sua captação: o aroma da erva doce.

\section{Figura 8. "Fennel and Hedge", Rosita Mckenzie}

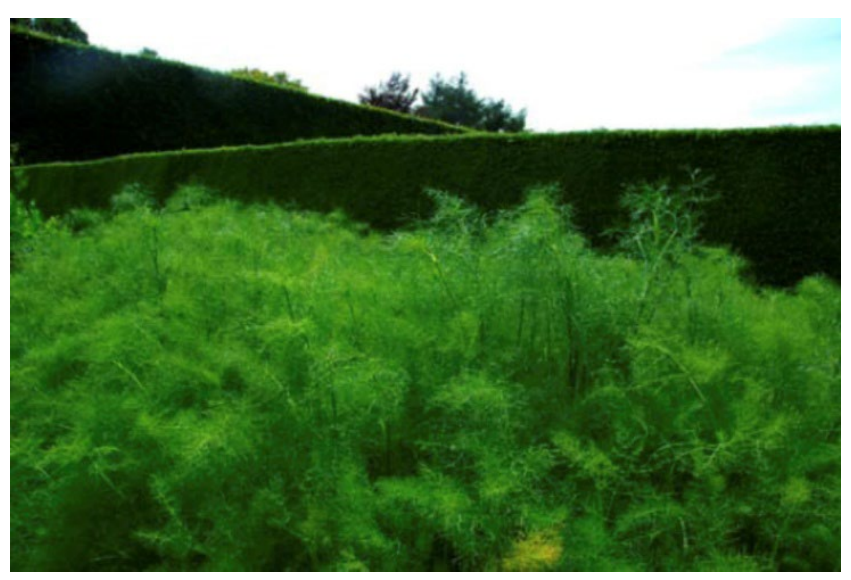

Fonte: Catálogo da exposição Sight Unseen (2009), p. 54.

As imagens apresentadas por Bruce Hall resultam das sensações corporais da experiência de contato com seus sobrinhos gêmeos autistas, por um lado, e com o mundo aquático, por outro. $\mathrm{Na}$ imagem "Silhueta" (Figura 9 - "Silhouette"), temos uma fotografia subaquática que retrata, em primeiro plano, um amontoado de algas subindo pelas duas laterais da foto, sugerindo que o próprio fotógrafo, ao tirá-la, estava fisicamente em contato não apenas com a água, mas também com essa vegetação aquática. As algas tomam todos os planos da imagem, exceto em uma brecha ao centro, que é também por onde entra a luz que converge para o quadrante central inferior da imagem, nos permitindo visualizar um pequeno peixe. 
Figura 9. "Silhouette", Bruce Hall

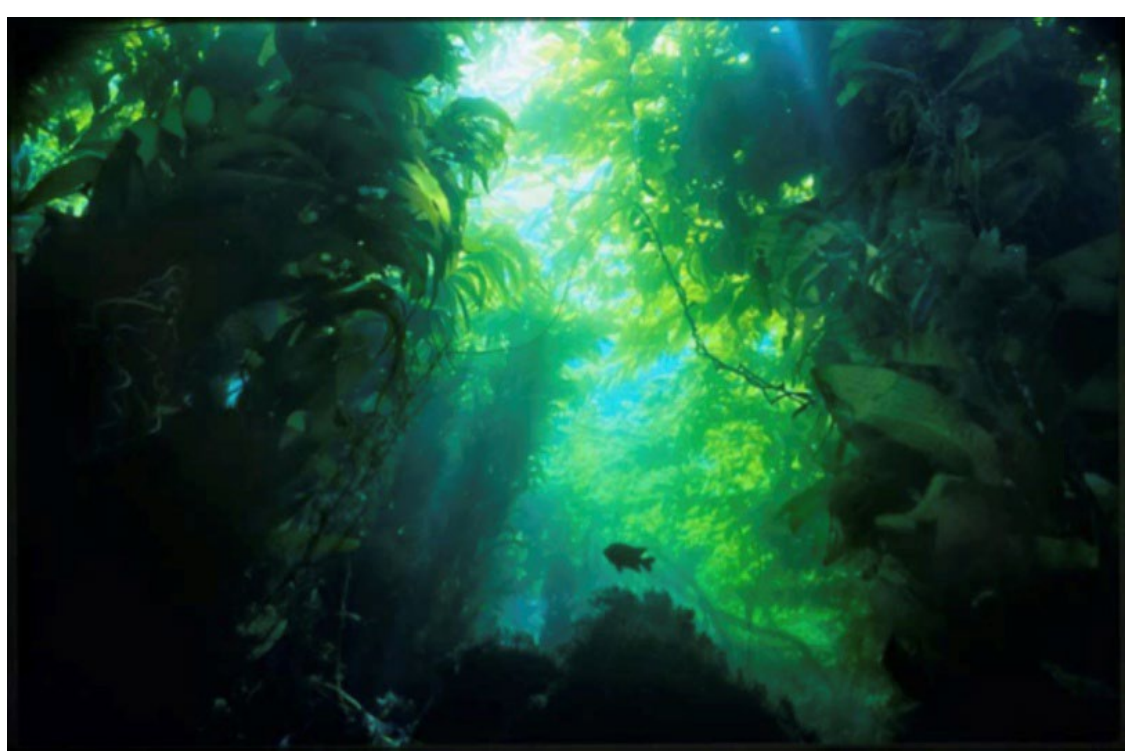

Fonte: Catálogo da exposição Sight Unseen (2009), p. 41.

Na imagem seguinte, "Frenético" (Figura 10 - "Frenetic"), temos em primeiro plano uma larga bolha de água que estoura espalhando uma série de gotas por toda a parte superior da imagem. Em segundo plano vemos a imagem de uma criança, um pouco desfocada pela película de água que está na frente dela. Ela está com a boca aberta e os olhos fechados e parece interagir com a água com alegria e entusiasmo. Ao fundo temos uma bacia azul com alguns brinquedos espalhados. A proximidade e a direção da água sugerem o engajamento do próprio fotógrafo na cena, a imagem foi tirada em movimento e ele participa ativamente da ação. 
Figura 10. "Frenetic", Bruce Hall

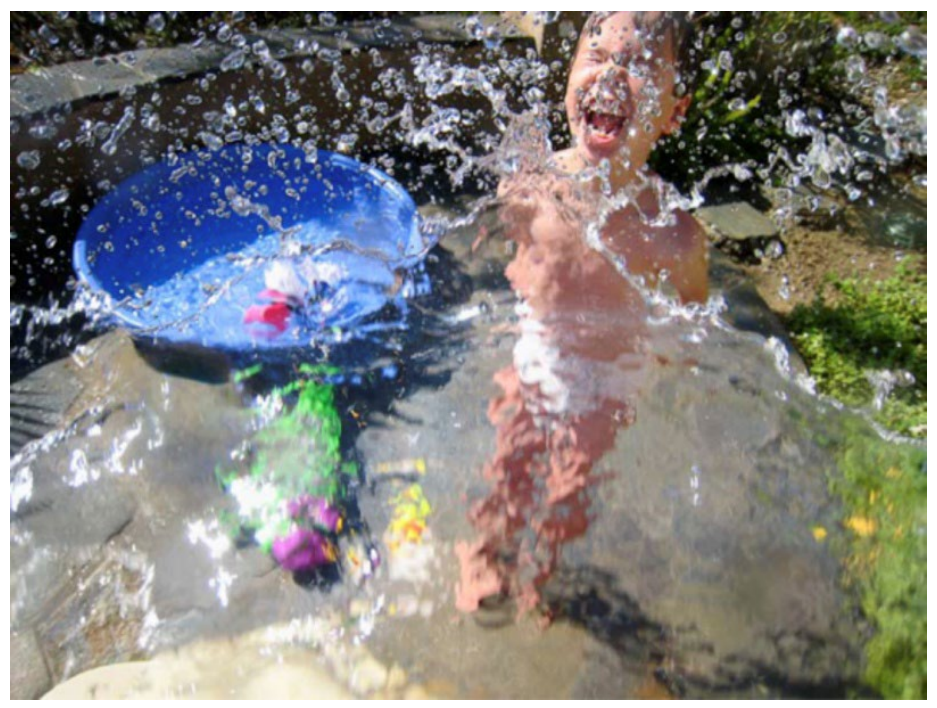

Fonte: Catálogo da exposição Sight Unseen (2009), p. 35.

Os mundos escolhidos por Bruce Hall como tema para as suas fotografias podem ser visitados e captados através de impressões ou vislumbres, mas ninguém pode verdadeiramente penetrar ou habitar. São desconhecidos que são experimentados fisicamente pelo fotógrafo, para então serem retratados por meio da interação com todo o corpo. Uma visão de dentro, de quem submerge na interação, não um olhar de fora, à distância. Esta forma de percepção e representação que se constrói pelo contato Sousa (2004) chamou de "mundividência tátil". Um modo particular de ser, perceber e estar no mundo que contém suas próprias especificidades, algumas delas ressaltadas na análise das fotografias táteis: o caráter sequencial e analítico da exploração tátil, a temporalidade mais lenta, a proximidade, o engajamento, a importância dos detalhes.

Nas fotografias analisadas no segundo grupo, vemos, portanto, processos de criação e produção de imagens que não estão estruturadas pela determinação visual, mas respondem ao estímulo de outras práticas sensoriais e perceptivas. Gerardo Nigenda, fotógrafo mexicano, adiciona às suas fotos descrições em Braile de suas percepções ao tirá-las - toque, sons, cheiros -, ressaltando o papel que tais percepções desempenham para estabelecer o local, 
a impressão e o próprio significado pessoal das imagens que tira. Aqui não há uma preocupação em dotar a foto de certas características previamente imaginadas para ela, mas sim permitir que as qualidades sentidas corporalmente no ato de fotografar um determinado ambiente saiam da própria foto, se transformando na presença perceptível de algo. Os elementos sensoriais representados não são apenas sinais que sugerem a cena fotografada, mas também produzem a cena em si, evocando uma "atmosfera" (Bohme, 1993).

Bohme (1993) resgata a dimensão de naturalidade e corporeidade no conceito de aura em Benjamin para propor uma teoria da nova estética, em que, primeiramente, a experiência da aura depende de uma impressão natural ou um "estado de espírito", além de uma certa receptividade do observador. Antes de estar nas obras de arte a aura aparece nos objetos naturais, é algo que se respira - é absorvida corporalmente, penetra o eu, entrando na economia corporal de tensão e expansão da pessoa. Bohme chama esse "e", ou esse "entre", por meio do qual os estados humanos e o ambiente se relacionam, de "atmosfera". A teoria estética que propõe está preocupada com a experiência, especialmente a sensível. Aborda a estética a partir da ecologia, se interessando pela relação entre as qualidades ambientais e os estados humanos. 0 que a nova estética busca compreender é justamente o processo de produção de atmosferas, não apenas na arte, mas também na escrita, na publicidade, no design, na jardinagem, entre outros campos.

A nova estética proposta por Bohme é, antes de tudo, uma teoria geral da percepção. Mas a percepção é entendida pelo autor não como fornecimento de dados e processamento de informações, ou o (re)conhecimento de uma situação, e sim a partir do impacto afetivo do que é observado, a "realidade das imagens" na corporeidade. Trata-se da experiência da presença: de pessoas, objetos ou ambientes. Podemos observar a qualidade estética da produção de atmosferas no trabalho de fotógrafos cegos, que remetem à presença das qualidades sensíveis das cenas fo- 
tografadas. O resultado são imagens que revelam sensações. Annie Hesse, fotógrafa que capta o ambiente por intermédio de impulsos sensoriais, é descrita como alguém que anda pelas ruas com o propósito de experimentá-las. Ela própria se define como uma "cidadã do mundo" e os retratos que tira em suas viagens são baseados em pressentimentos, suposições, impressões. Rosita Mckenzie diz que utiliza a câmera como resposta aos estímulos que recebe de fora, e exemplifica: "eu posso ser experimental, porque eu não enxergo. Ao invés disso, eu sinto a luz no meu rosto. Eu ouço o sussurro do vento nas árvores ou sinto a fragrância das flores no ar, então eu penso que eu realmente preciso registrar isso" (MCCULLOH, 2009, p. 50, tradução livre).

Merleau-Ponty (2004) procura compreender a obra e a vida de Cézanne como uma comunicação, um intercâmbio. A forma que dava a seus quadros era a maneira como percebia o próprio mundo - estava presente no mundo, nas coisas, nos rostos -, e o que fazia era apenas liberá-los. O autor identifica na pintura de Cézanne um paradoxo: procurar a realidade sem abandonar as sensações, sem outro guia senão a própria natureza na impressão imediata, não delimitando contornos, não enquadrando a cor pelo desenho, sem compor a perspectiva ou o quadro. As imagens registradas pelos fotógrafos cegos deste grupo procuram, por meio de um equipamento que gera um resultado visual, que congela uma cena, revelar suas impressões extravisuais do mundo, impressões sensoriais que conformam a sua percepção e - porque não - a sua visão de mundo. Neste sentido, podem ser compreendidas como um paradoxo semelhante ao da pintura de Cézanne: buscam congelar o tempo, mostrar a realidade, mas sem abandonar as sensações. Ao mesmo tempo são imagens descritas como vívidas, "deliciosamente arbitrárias", puras, exploratórias, que se não podem emitir cheiros, ventos, barulhos, remetem o observador aos odores, toques, sons às atmosferas que as inspiraram.

Soulages (2017) reconhece o sujeito criador na fotografia como aquele que parte não mais da realidade, mas que toma como tarefa fazer uma imagem em função de imagens já existentes, seja 
como inspiração, como desvio, seja por estar marcado por elas. Sugere ainda que podemos enriquecer o conceito de imagem ao considerar não apenas o seu sentido material, mas também os significados dados pela imagem poética, literária, ideológica, metafórica, psíquica, sentidos estes que, para o autor, devem ser integrados no conceito de "imagem de imagens". As "imagens de imagens" criadas por fotógrafos cegos deste segundo grupo dão a ver suas representações extravisuais do mundo: são imagens de imagens sonoras, imagens de imagens táteis, imagens de imagens olfativas. Com isso, o que a fotografia de cegos transforma não é tanto a recepção de uma obra de arte, mas os próprios parâmetros sensíveis da realidade, estabelecendo, para o espectador, pelos referenciais sensoriais que vazam da imagem, ligações que talvez ele próprio não retivesse daquele contexto.

Para Mondzain (2010), as imagens não são como objetos posicionados em frente aos nossos olhos, mas, ao invés disso, são lugares em que os signos podem circular entre nós sem interrupção. A produção de imagens, a faculdade de imaginar, não está relacionada apenas ao visual, mas à possibilidade de representar. A representação pode adquirir contornos visuais, mas também comportamentais, sonoros, materiais, táteis, oníricos. A associação da visão com a visualização parece ofuscar os múltiplos significados embutidos na palavra imagem. Dora, uma das pessoas cegas congênitas com quem trabalhei na pesquisa que realizei no doutorado (VON DER WEID, 2014), fala sobre o aspecto polissêmico da imagem:

É que imagem para mim ela não é só visual. Imagem pode ser uma imagem auditiva... imagina aquela música, imagina o som de harpa. Pode ser uma imagem tátil, imagina aquele lençol de seda. Pode ser uma imagem olfativa - "imagina aquele chocolate com baunilha". Ou pode ser uma imagem gustativa e até pode ser uma imagem proprioceptiva - "imagina que você está pulando de um trampolim", é uma imagem proprioceptiva, ela não é tátil, ela não é exatamente nenhum dos cinco sentidos. E pode ser - 
"imagina que você está triste". Então imagem é uma coisa muito rica. A gente tem uma cultura que é predominantemente visual, então é uma cultura que bota tudo no visual, visualiza tudo e acha que com a visão vai resolver.

Verine (2013) considera que, na sociedade atual, a uma experiência humana multissensorial, intermodal e mesmo holística, correspondem a representações quase exclusivamente visuais. Haveria o que se chama de "pregnância sociocultural do visível", fenômeno também subentendido em termos como "oculocentrismo" (JAY, 1999) e "visuocentrismo" (FABIAN, 2014). Existiria um círculo vicioso entre a pregnância do olhar nas práticas e discursos socialmente valorizados e a dificuldade das pessoas, cegas e não cegas, de falar sobre suas experiências não visuais. Cada um, a sua maneira, silencia as alternativas à visão, ora remetendo o perceptível e o percebido a equivalentes visuais ou abstrações, ora inferiorizando ou depreciando os outros sentidos.

O silêncio sobre sensações não visuais que repercute em discursos e nas representações culturais é entendido por Verine (2013) como uma obnubilação pelo visível. As imagens aqui analisadas também sugerem que há todo um mundo sensorial e imagético relevante, que não pode ser sobreposto ao mundo relevante da visualidade, mas, antes, deve ser revelado em toda a sua especificidade, sua beleza e sua complexidade. Conhecer tais imagens ressaltando suas diferenças, e não a similitude com imagens geradas pela visualidade, é uma aposta na direção de desvendar tal conhecimento como uma estética singular e como legado para todos, cegos ou não cegos.

\section{O olho tecnológico}

Parte dos fotógrafos da exposição é considerada "legalmente cega", ou seja, ainda mantém um fragmento de visão bastante limitada e atenuada do mundo externo. O uso do equipamento 
fotográfico, para além da produção de imagens, tem um significado específico para eles: fotografam com o objetivo de ver. Por meio de dispositivos visuais como câmeras, lentes de aumento ou monitores de alta definição conseguem visualizar, posteriormente, o espaço e o mundo que clicaram. Vivem em um espaço visual criado por um olhar ampliado pelo uso da tecnologia.

Ao contrário do que se poderia supor o termo cegueira não nos dá uma definição absoluta, pois entre as extremidades visão normal e cegueira total - ou visão zero, como também se usa em oftalmologia - existe um número significativo de pessoas com diferentes graus de visão remanescente que são consideradas cegas. Ao invés da cegueira ser plana, ela se multiplica. Os chamados "resíduos visuais" ou "grau de visão mantido" (RODRIGUES, 2014) podem ser a percepção de luminosidade, quando se consegue fazer a distinção entre claro e escuro, a percepção da projeção luminosa, quando se identifica também a direção de onde provém a luz ou a percepção de vultos, por exemplo. São estes rastros de luz e a interação entre luz e sombra que vão guiar os registros desse grupo de fotógrafos.

Anne Hesse tira suas fotos baseada na curiosidade, em pressentimentos ou vultos. Posteriormente, por meio da foto tirada, redescobrirá visualmente a situação vivida. $\mathrm{Na}$ imagem "Torre Eiffel" (Figura 11 - "Eiffel Tower"), temos um plano de câmera baixa que mostra um recorte da construção da torre por dentro. A parte de cima está iluminada pelo sol, ressaltando o tom cobre das barras de ferro que se entrecruzam de forma ascendente em direção a um céu azulado. A parte de baixo está na sombra, contrastando com a zona iluminada. 
Figura 11. “Eiffel Tower", Annie Hesse

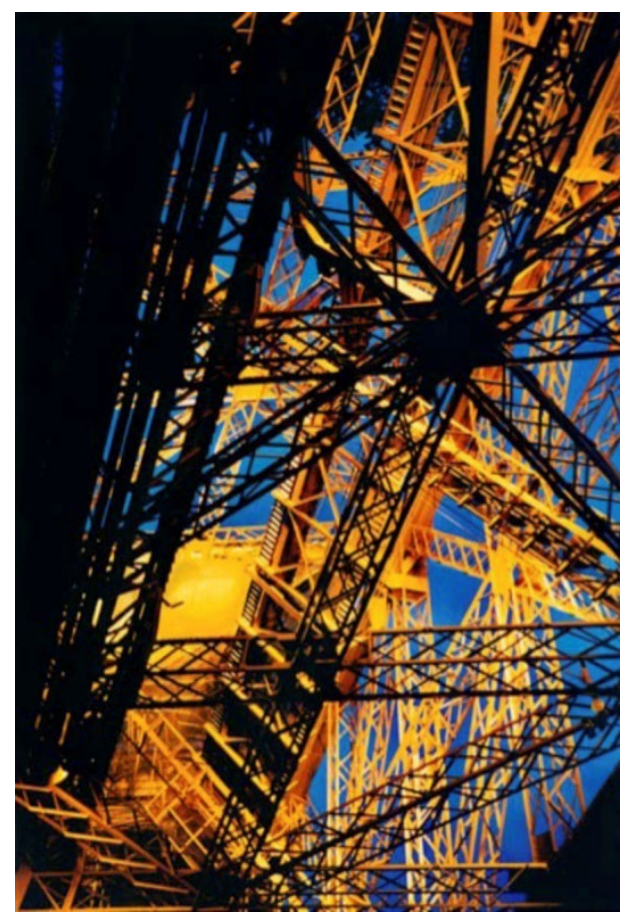

Fonte: Catálogo da exposição Sight Unseen (2009), p. 43.

Bazin (1991) argumenta que as virtualidades estéticas da fotografia residem na revelação do real. Por meio da impassibilidade da objetiva, a foto nos permite admirar em sua reprodução o original que os nossos olhos não teriam sabido amar. Para os olhos de artistas como Bruce Hall e Anne Hesse, mais do que a chance da admiração posterior, a fotografia torna possível a própria existência de um mundo visual. Bruce Hall diz no catálogo que muitos fotógrafos observam para então fotografar, mas, em seu caso, ele fotografa para ver. Não pode ver nada sem o auxílio de dispositivos ópticos. Sua relação com a câmera passa por uma obsessão: "está além de ser apaixonado por câmeras, eu necessito delas" (MCCULLOH, 2009, p. 34, tradução livre). O fotógrafo chama tal interface com o mundo de "visão intensificada". Os dispositivos são como extensões, amplificações do seu corpo.

As fotografias que esse grupo produz existem na lacuna entre as limitações do olhar físico e o desejo por imagens. Uma fração do ambiente externo que por alguma razão vira foco de seu inte- 
resse também se transforma em um novo mundo a ser descoberto e revelado para aqueles que enxergam. $O$ trabalho de Michael Richard, que se utiliza de lentes de aumento para fotografar, é descrito como "cheio de descobertas improváveis, estranhos equilíbrios geométricos, vistas formais torcidas, e pequenos detalhes deliberadamente vistos" (MCCULLOH, 2009, p. 80, tradução livre). Na imagem "Várias Camadas" (Figura 12 - "Strata Various"), temos um plano de câmera baixa que aponta para uma construção e o que vemos são uma série de janelas quadradas de vidro que refletem a sacada de outro prédio e também um pedaço do céu. A imagem no reflexo aparece distorcida e arredondada, gerando uma forma inusitada. A foto foi tirada em preto e branco, deixando bastante vívido o contraste entre luz e sombra.

Figura 12. "Strata Various", Michael Richard

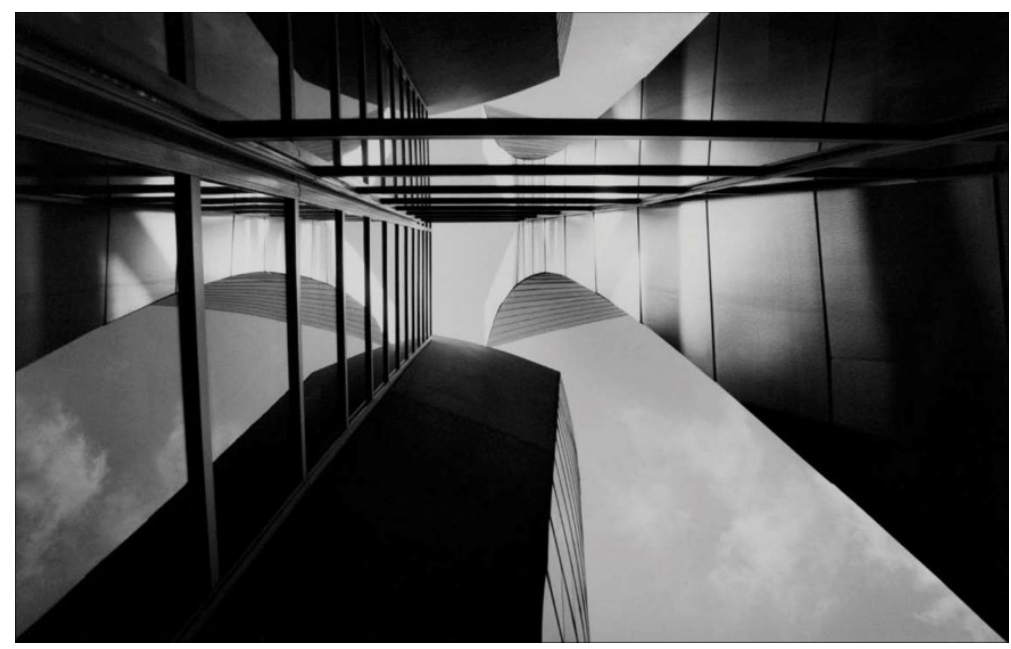

Fonte: Catálogo da exposição Sight Unseen (2009), p. 81.

Segundo o próprio artista ele só pode controlar o tema de interesse até certo ponto, então precisa aceitar e seguir seus instintos, deixando esse tema ditar a forma como tira a foto. Na imagem seguinte, "Saída" (Figura 13 - "Way out"), vislumbramos, através de um plano de câmera baixa, o que parece ser uma saída de metrô. Os corrimões da escada estão iluminados pela luz que vem de fora e conduzem os olhos do espectador para parte de cima da foto, 
onde vemos, através de um buraco formado pelo contraste entre luz e sombra, um pedaço de céu nublado e um prédio ao fundo.

Figura 13. "Way out" - Michael Richard

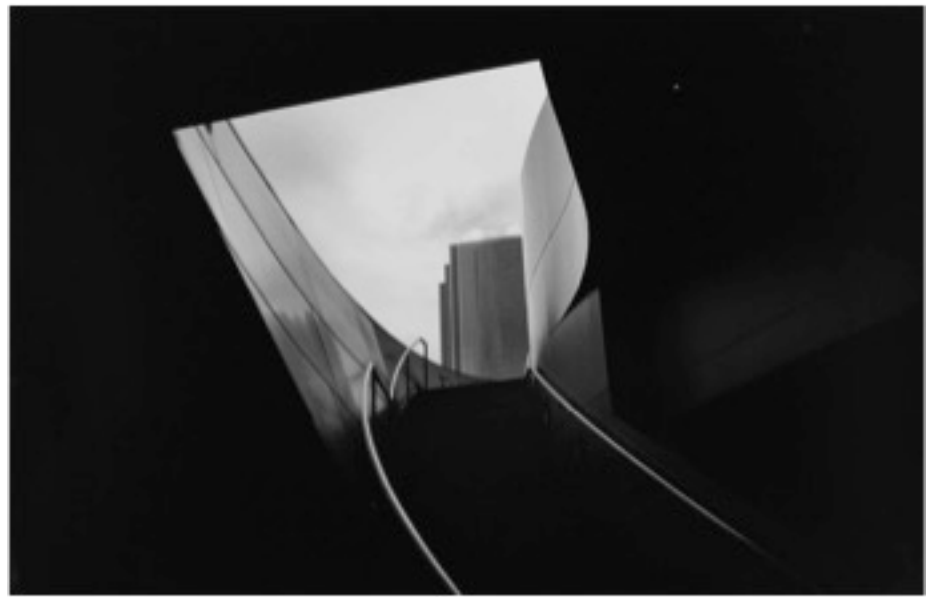

Fonte: Catálogo da exposição Sight Unseen (2009), p.89.

Uma característica física - a fisiologia dos olhos - possibilita a estes fotógrafos captarem o mundo de formas inesperadas, não imaginadas por aqueles que enxergam, o que parece posicioná-los em um lugar especial no próprio segmento artístico a que pertencem. Diferentemente do grupo anterior, para esses fotógrafos a qualidade e a quantidade de luz disponível no ambiente é aqui um elemento importante, talvez o principal elemento que conduz a sua prática fotográfica. A entrada de luz e a forma como reflete nos materiais dos ambientes também interfere na sua percepção visual, bem como o contraste, que favorece a visualização.

A interferência da tecnologia digital, o seu desenvolvimento e criação de novas lentes cada vez mais potentes, monitores ampliados ou novos recursos em termos de equipamento digital são contribuições fundamentais para esses artistas. Sua intenção original não é exatamente produzir imagens que sejam vistas como arte, mas produzir imagens para si próprios, a fim de visualizarem o mundo, construindo, assim, o seu acervo imagético. Para a fotógrafa Annie Hesse, sua memória visual é a memória da câmera. 
Segundo ela, "para alguém que tem tido a visão comprometida por toda a vida, sou uma pessoa extremamente orientada visualmente. A fotografia criou o meu mundo. Ela para o tempo e eu absorvo aquilo depois" (MCCULLOH, 2009, p. 42, tradução livre).

Haraway (1991) descreve as tecnologias de comunicação e as biotecnologias como ferramentas cruciais no processo de remodelação de nossos corpos. Para a autora, no final do século XX já éramos todos quimeras, híbridos - teóricos e fabricados - de máquina e organismo; já éramos todos ciborgues. Clark (2003) também defende esta ideia, não meramente no sentido superficial de combinar carne e ferro, mas no sentido mais profundo de sermos simbióticos humano-tecnológicos: sistemas de pensamento e razão cujas mentes e corpos estão espalhados por cérebros biológicos e circuitos não biológicos. Para o autor, seres humanos são ciborgues desde o nascimento. Nos dias atuais é difícil imaginar corpos que não sejam já marcados, equipados e estendidos por dispositivos.

Clark e Chalmers (1998) desenvolvem uma reflexão sobre a cognição estendida em torno da seguinte questão: onde é que termina a mente e o resto do mundo começa? Defendem uma resposta para a pergunta a partir do que chamam de "externalismo ativo", baseado no papel ativo desempenhado pelo ambiente ou por dispositivos tecnológicos na condução de processos cognitivos. Os autores acreditam que o organismo humano pode se vincular a uma entidade externa criando um sistema acoplado que pode ser visto como análogo a um sistema cognitivo. Todos os componentes do sistema desempenham um papel causal ativo e em conjunto eles governam o comportamento da mesma forma que a cognição usualmente faz. Se removermos os componentes externos - a câmara fotográfica, as telas de computador, projetores ou outros mecanismos de ampliação da imagem -, a competência comportamental do sistema, neste caso a visualização, acaba.

Se pensarmos o trabalho dos fotógrafos desse grupo, nos termos de Becker (2008), podemos dizer que sua motivação para fotografar não é necessariamente fazer arte, passa por algo mais 
primordial, que é a possibilidade de ver o mundo. Para isso fazem um uso específico do equipamento que transforma suas imagens em foco de interesse estético para os demais integrantes do mundo da arte. O juízo e as premissas que classificam seus trabalhos como artísticos são formados por críticos, curadores, outros fotógrafos ou o público em geral. Ao invés de serem assoberbados pelos estímulos visuais característicos de nossos tempos, constroem seu mundo visual com uma imagem de cada vez.

\section{Observar o invisível - aspectos comunicativos}

Há ainda um ponto relativo à comunicação que parece permear o trabalho desses fotógrafos e que os liga talvez de forma mais necessária à rede cooperativa que compõe o mundo da arte, de que nos fala Becker (2008). Suas imagens, para existirem para eles próprios, precisam existir para outros. A partir da comunicação, do relato e da descrição das fotos por outras pessoas é que ganham materialidade para eles mesmos. Bavcar (2003) acredita que, assim, consegue alcançar a síntese entre palavra e imagem; quem descreve suas fotos coloca uma palavra sobre aquilo que ele mostra. O fotógrafo e filósofo esloveno argumenta que, se não se pode nunca observar o sonho de uma pessoa se ela não o comunicar, da mesma forma, ele próprio não poderá jamais ver suas fotos com o seu olhar físico, mas, a partir da descrição de amigos e pessoas próximas, consegue ter sua representação verbal. Através do invento da câmera fotográfica o fotógrafo cego dá ao mundo o que ele próprio não tem.

O crítico fotográfico Alfonso Morales, ao comentar no catálogo o trabalho de Gerardo Nigenda, aponta que é necessária uma relação íntima com pessoas que podem ver para completar o ciclo que começa com um registro mecânico e termina com uma reconstrução mental da cena fotografada. As imagens captadas por Gerardo Nigenda são uma espécie de cegueira dupla, elas vêm 
acompanhadas por descrições em Braile das sensações do autor ao captar a imagem, que a maior parte das pessoas que enxergam não são capazes de ler sozinhas. O próprio fotógrafo precisa de uma pessoa que enxerga para descrever a imagem visual que gerou para si mesmo, mas quem enxerga também precisa de uma pessoa cega que leia as imagens sensoriais - táteis, auditivas, proprioceptivas - que também fazem parte do resultado final da obra, gravadas na foto pela escrita em relevo. Com isso ele constrói uma espécie de ponte entre o mundo da cegueira e o mundo da visão. Na fotografia a seguir (Figura 14), tirada em preto e branco, percebe-se em primeiro plano o colo desnudo de uma mulher, com os cabelos longos voltados para frente, escorrendo pelos dois lados em direção aos seios. A mão esquerda do fotógrafo aparece em cena, e seu toque parece ter seguido a direção dos cabelos, pois seus dedos estão apoiados nas pontas dos fios que terminam entre os seios da mulher. Um dos mamilos, o esquerdo, aparece na cena e ela está com o braço em curva, aparentemente com a mão apoiada na cintura, embora ela não apareça. Em segundo plano se vê um lençol branco, levemente amarrotado.

Figura 14. "Coinciding calm and silky sensations", Gerardo Nigenda

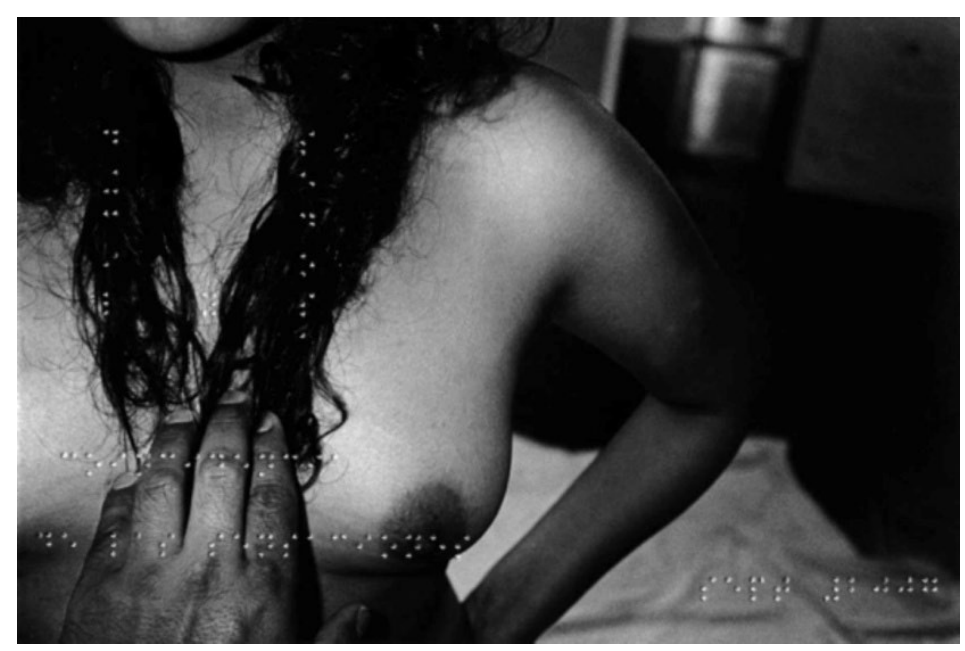

Fonte: Catálogo da exposição Sight Unseen (2009), p. 74. 
Interessante observar que as descrições em Braille não estão dispostas do modo convencional, horizontalmente da esquerda para a direita, mas seguem o motivo que está em primeiro plano na foto, a mulher. Os códigos estão dispostos na direção dos seus cabelos escorridos e, em seguida, no colo e entre os seus seios. Para fazer a leitura da inscrição na foto - "Coincidindo sensações calmas e habilidosas" ("Coinciding calm and silky sensations"MCCULLOH, 2009, p. 74, tradução livre) - é como se a pessoa cega repetisse o gesto realizado pelo fotógrafo ao tirá-la. Só que, dessa vez, a leitura tátil da cena ocorre por intermédio das palavras, não das sensações.

Bavcar (2003) ressalta outro ponto de seus retratos que remete à interação fotógrafo e fotografado, especialmente, a interação não visual entre quem enxerga e quem não enxerga. Por ser cego, o artista dá às pessoas que fotografa a possibilidade de olharem para o infinito, porque detrás da câmera não existe uma instância de controle, alguém que a todo momento vigia o olhar do outro. Para ele, as pessoas ganham uma aparência diferente quando são confrontadas com o desconhecido, ou o que imaginam ser a escuridão infinita. A sua deficiência visual estimula, assim, um aspecto novo, inesperado, para os retratos que produz.

Goffman (1996) define a noção de interação como a influência recíproca dos indivíduos sobre as ações uns dos outros quando em presença física imediata. Para uma interação ocorrer, em uma situação social qualquer, não necessariamente é preciso que uma comunicação verbal aconteça. Um indivíduo pode definir a situação na sua apresentação de si a partir de sua "fachada pessoal", que inclui características como vestuário, sexo, idade, altura, aparência, padrões de linguagem, expressões faciais ou gestos corporais. Todas as características, que compõem uma "fachada", mencionadas pelo autor, à exceção dos padrões de linguagem, estão situadas em uma percepção de mundo centrada no olhar.

Os sistemas classificatórios por meio dos quais o significado é produzido dependem de sistemas sociais e simbólicos. Princípios de classificação e de diferença organizam a vida social, atribuindo 
valores arbitrários a determinados grupos de acordo com a aparência ou com atributos físicos como cor da pele, o sexo, a deficiência ou mesmo qualidades estéticas (WOODWARD, 2014). O aspecto da visibilidade é um dos ressaltados por Goffman (1975) na relação que transforma um atributo diferenciado em estigma. É ser necessariamente visto em todos os lugares que frequenta. Não é apenas um olhar que nota a presença de alguém novo que chega a um ambiente, mas um olhar que escrutina: olhar fixo, olhar curioso, olhar de espanto, olhar aterrorizado, olhar sedutor. Notar, reparar, ver, observar; a sensação de ser sempre visto e virar "atração" que a pessoa com deficiência enfrenta no seu dia a dia, Garland-Thomson (2009) chama de "olhar fixamente" ou "encarar" (stare), que está relacionado à estigmatização.

Como sugere Bavcar (2003), a interação entre pessoas cegas e outras não faz pausar um sistema de representação e atribuição de sentido fundado em marcas e traços visíveis. Possivelmente porque também carregam uma identidade social estigmatizada, mas também pela interrupção do mundo das aparências que a cegueira provoca, a comunicação entre aquele que vê, mas não é visto, e aquele que não vê, mas é visto, parece momentaneamente suspender o processo de reprodução de identidades hegemônicas na apresentação de si, convidando àquele que é fotografado a expressar outras faces de si mesmo ${ }^{4}$.

\section{Convenção e invenção na produção de imagens}

Uma ideia que perpassa o texto de apresentação da exposição é que as imagens geradas pelos fotógrafos cegos apresentam uma característica que os distingue em relação aos demais fotógrafos: por não enxergarem, conseguem ir além das regras formais do mundo da fotografia. Para Becker (2008), as convenções de um mundo da arte supõem uma forte limitação para o artista; e são especialmente limitadoras porque não existem isoladas, fazem

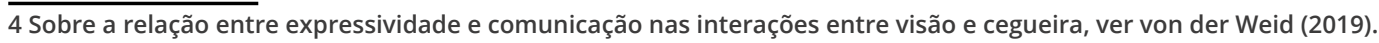


Fotografias de cegos: olhar além da visão

parte de um complexo de sistemas interdependentes, presente nos equipamentos, nos materiais, na formação, nos lugares. Em relação à fotografia, as convenções que indicam os aspectos que uma boa foto deve ter implicam não apenas em uma estética mais ou menos aceita pelos que participam da produção de fotografias, mas também que tais limitações sejam incorporadas nos próprios equipamentos e nos acessórios padronizados que são produzidos pelos grandes fabricantes. As convenções de avaliação e ensino da fotografia abrangem o exercício da visualidade: composição da imagem, enquadramento, momento decisivo da cena fotografada, manter pessoas e objetos não desejados - o mundo real - fora da foto ${ }^{5}$. Becker indica que as limitações das convenções não são totais, sempre é possível fazer as coisas de outra forma quando se está disposto a pagar o preço de um esforço maior, ou da menor circulação do próprio trabalho. Se os dispositivos fotográficos carregam em sua materialidade o pressuposto de seu uso por um certo tipo de corpo - o que enxerga - sua manipulação por pessoas cegas envolve necessariamente o exercício inventivo de novas técnicas corporais (MAUSS, 2003). Kulcsár (2018), que relata sua experiência de ensino de fotografia para pessoas com deficiência visual, explicita algumas das práticas desenvolvidas em aula para a realização da imagem por pessoas cegas, entre elas o toque nos ombros para reconhecer a altura do fotografado, no caso de retratos, ou o conhecimento da distância do fotografado em relação ao fotógrafo a partir da emissão do som da voz.

$\mathrm{Na}$ apresentação do catálogo, fazer as coisas de forma não convencional se transforma no argumento estético que valoriza e distingue o trabalho de fotógrafos cegos em relação a outros fotógrafos. Não ser capaz de ver a cena fotografada acrescentaria um ganho às imagens produzidas: liberdade ao invés de controle. A cegueira significaria uma libertação dos usos convencionais do equipamento. As imagens de Rosita Mckenzie, por exemplo, são apresentadas como impregnadas de uma liberdade que vem com

5 São "dicas" e "diretrizes" que podem ser encontradas em qualquer manual de fotografia. Ver, por exemplo, o site da Nikon: https://www.nikon.pt/pt_PT/learn-and-explore/photography-articles.tag/learn_and_explore/photography_articles/5-easy-composition-guidelines.dcr. Acesso em: 20 set. 2019. 
o não enxergar. Segundo a artista, ela "segura sua câmera no comprimento de um braço, a coloca no chão, segura acima da cabeça" (MCCULLOH, 2009, p. 50, tradução livre). As fotos são apreciadas justamente por conterem o acaso, a surpresa, o inesperado, por ultrapassarem, de forma criativa, o universo das regras e das convenções.

Huyssen (2000) chama atenção para uma nova estrutura de temporalidade, gerada, por um lado, pelo ritmo cada vez mais rápido da vida material e por outro, pela aceleração das imagens e das informações da mídia. Para o autor, a velocidade destrói o espaço e apaga a distância temporal, alterando o mecanismo da percepção psicológica. A simultaneidade e a presentificação sugerida pelo imediatismo das imagens é em larga medida imaginária, criando suas próprias fantasias de onipotência. Essa simultaneidade vai abolindo a alteridade entre passado e presente, tendendo para a perda da ancoragem no real, e o presente sucumbe ao poder mágico de simulação e projeção de imagens.

É na oposição deste processo descrito por Huyssen que se ancora a justificativa do argumento estético e conceitual do trabalho de fotógrafos cegos. A visão, no mundo contemporâneo, seria tão persuasiva e poderosa que tornaria as pessoas inconscientes de sua própria cegueira. $O$ fato de enxergar seria tão forte a ponto de nos fazer acreditar que, apenas por ver, compreendemos o mundo. A crítica se constrói especialmente em relação aos fotógrafos profissionais (não tanto os artistas) que, normalmente vistos como especialistas do olhar, são apontados como os mais "cegos". As convenções da fotografia, a forma de ensinar, a facilidade de acesso a equipamentos fotográficos de qualidade teriam nos levado a um estreitamento da visão, a uma cegueira progressiva. Vivemos em uma era visual, inundados de imagens que são usadas para construir nosso próprio mundo. Os fotógrafos teriam infligido a todos sua própria cegueira, que se tornou contagiosa. Douglas McCulloh (2009) usa como exemplo o choque que se experimenta em uma viagem quando se visita lugares ícones: a realidade é desapontadora se comparada à imagem divulgada 
do lugar. As colocações remetem à ideia de Barthes (2008) sobre a fotografia nos tempos modernos, quando ele diz que é como se a imagem, universalizando-se, produzisse um mundo sem diferenças (indiferente).

$\mathrm{Na}$ argumentação crítica e estética que busca valorizar o trabalho de fotógrafos cegos, a dicotômica visão versus cegueira se inverte, baseada na justificativa de uma visão interna mais profunda, mais limpa, mais verdadeira, em oposição a uma visão externa excessiva, superficial, mentirosa. Fotógrafos cegos, por não terem a possibilidade de perceber o mundo com o olhar, estariam protegidos do excesso e bombardeio de imagens que compõe o mundo atual. Ao mesmo tempo, não teriam os vícios das convenções fotográficas, que também passam pelo olhar. Para Becker (2008), as discussões sobre a estética das obras de arte não seriam apenas uma questão filosófica, mas também uma batalha por reconhecimento. Procura-se criar juízos e reputação das obras e dos artistas por meio de uma forma defensável de excluir coisas. No caso dos fotógrafos cegos, a sua aparente desvantagem se transforma em vantagem em relação aos fotógrafos que enxergam que, de tanto verem, seriam cegos para a imaginação: "é o mundo que está cego: existem imagens demais, uma espécie de poluição. Ninguém consegue ver nada. Você precisa eliminá-las para descobrir imagens verdadeiras" (MCCULLOH, 2009, p. 5, tradução livre). Sua aproximação do mundo estaria emancipada da imersão na mídia visual.

O discurso que apresenta as imagens de fotógrafos cegos sugere que, para além da realidade da coisa em sua reprodução, para além de uma crença na existência do objeto representado, as fotografias de cegos trariam em si um excedente para aqueles que as podem ver: a representação imagética de uma percepção não visual do mundo. A justificativa estética da exposição utiliza argumentos que defendem uma aproximação entre uma concepção mesma de arte e a cegueira. A arte se basearia na ideia de que simples realidades físicas contêm misteriosos significados latentes. Estes fotógrafos seriam capazes de unir o mundo visível e o invisível através de suas imagens. Por não enxergarem o mundo 
físico, alcançariam o significado oculto para além dele. Se aqueles que enxergam estão cegos por muito verem, os fotógrafos cegos, por contraste, estão livres pela deficiência ocular. Podem assim desenvolver uma experiência interna, uma aproximação espontânea do mundo, desobstruída das convenções. Produziriam uma arte da mente, uma arte da "não retina", do conceito, da sensação, da experiência, da oportunidade.

McCulloh (2009) retoma nesse argumento uma das mais antigas representações culturais sobre a cegueira na mitologia Ocidental: a do cego vidente. Emblemática na figura de Tirésias, tal versão da cegueira materializa uma ruptura na associação entre visão e conhecimento. Em Tirésias, Martins (2006) identifica a origem da construção do cego como adivinho, cuja incapacidade de ver o que os outros veem lhe permite ver o que ninguém mais vê. O homem cego é o detentor da verdade divina, instância do saber em quem as trevas físicas convive com a luz reveladora. A inversão estabelece uma relação de intimidade entre a cegueira e formas de conhecimento consideradas sobre-humanas, uma vez que o modelo "padrão" de humanidade é o de corpos que enxergam. Embora seja um imaginário social que reconhece na cegueira formas de conhecimento que se diferenciam da visão, o risco de seu exagero é encerrar as vivências de pessoas cegas em interpretações que as ligam ao fantástico, a "outros mundos". Para apreciar as imagens geradas pelos fotógrafos cegos em sua diferença, mas sem cair no exotismo, acredito ser necessário desestabilizar uma imagem bastante consolidada no pensamento moderno: a forma como se compreende o processo de representação e o "realismo" pressuposto na visão.

\section{Olhar além da visão}

Para explicar como enxergamos é bastante comum, nos textos oftalmológicos, a analogia entre o funcionamento do olho e 
o funcionamento de uma câmara fotográfica. O olho agiria como uma lente convergente que possui índice de refração e curvatura específicos para focalizar as imagens e raios luminosos na retina:

1. A córnea, camada mais externa do olho, faz o papel da objetiva da máquina, fazendo a refração.

2. A íris faz o controle da iluminação, que é realizada pelo diafragma da máquina fotográfica.

3. O cristalino é responsável pelo foco de objetos longe e perto.

4. A retina capta a imagem, como se fosse o cartão de memória da máquina fotográfica. (MOREIRA, 2014, p. 68)

A identidade entre o funcionamento da visão e o funcionamento de uma câmara fotográfica explicita uma determinada concepção de corpo, de mundo e de conhecimento que opera por meio de um completo desenraizamento do funcionamento da visão de qualquer referente - aquele que olha, aquilo que se olha ou o lugar de onde se olha. Ao longo do século XIX, por meio de experiências associadas à produção de pós-imagens na retina, Crary (1999) mostra como se constituiu uma nova positividade da visão. $\mathrm{O}$ olho foi sendo mapeado com zonas de eficiência e aptidão variáveis e parâmetros específicos de visão normal e patológica. A superfície física do olho se torna um campo de informação estatística: a retina é demarcada, indicando como as cores mudam de tonalidade dependendo de onde atingem o olho; a extensão da área de visibilidade é medida - a visão periférica; estabelece-se a distinção entre visão direta e indireta; localiza-se o ponto cego. A descrição oftalmológica sobre a visão central e visão periférica pode servir de exemplo do conhecimento sistemático produzido sobre o olho e suas funções. A acuidade visual se torna a medida para a visão central e o campo visual para a visão periférica.

A visão passa a ser estudada a partir de regularidades abstratas mensuráveis, cujo funcionamento, não à toa, passa a ser comparável ao de uma máquina (a câmera fotográfica). Crary (1999) localiza aí as fundações da moderna teoria de estímulo-resposta da psicologia. É também nesse momento que se inicia o gradual 
parcelamento e divisão do corpo em sistemas e funções cada vez mais separados e específicos. Especial importância é dada à localização do cérebro e das funções dos nervos e à distinção entre nervos sensoriais e nervos motores. Tudo isso produz uma nova verdade sobre o corpo que alguns autores relacionam à chamada separação dos sentidos no séc. XIX. Nessa separação Crary encontra uma quebra ainda maior com o observador clássico, com o surgimento de um observador para quem a visão é concebida sem nenhuma conexão com o ato de olhar. O observador se torna, simultaneamente, o objeto do conhecimento e o objeto de procedimentos de estímulo e normatização que tem por função essencial produzir experiências para o sujeito. A fonte da experiência se torna indiferente: "O sujeito que percebe se transforma em um condutor neutro, um tipo de relevo entre outros que possibilita ótimas condições de circulação e de trocas - de mercadorias, energia, capital, imagens ou informação" (CRARY, 2012, p. 95). A modernidade implica uma decodificação e desterritorialização da visão, gerando um observador móvel, útil e produtivo, um observador adequado aos novos usos do corpo e à vasta proliferação de imagens igualmente móveis e permutáveis.

Na modernidade, a visão foi desencarnada do corpo por meio de técnicas disciplinares que racionalizam a sensação visual e administram a percepção para desenvolver uma atenção visual mais acurada (CRARY, 2012). A separação e especialização dos órgãos dos sentidos, a concepção da visão como um processo mental interno, dissociado do ato de olhar, e a ideia de que o corpo seria uma espécie de condutor neutro de estímulos e sensações que são produzidas no cérebro, são noções que conformam um ideal normativo do que significa visão.

Ingold (2008) acredita que a ambivalência entre o olho e a mente como locus primário da visão ou, ainda, a ambivalência da visão como observação corporal ou especulação mental, que aparecem na descrição do funcionamento do olho da oftalmologia e também permeia a abordagem de Crary, nunca foi resolvida. Para o autor, as questões que são levantadas sobre o significado da luz são mal 
formuladas porque continuam a considerar os órgãos dos sentidos como portais entre um mundo externo e físico e um mundo interno da mente. Ingold (2008) considera que tal interface entre o olho e a mente não existe. Longe de começar com uma radiação de luz incidente e terminar como uma imagem mental, a visão consistiria em um processo interminável, um engajamento de mão dupla entre o preceptor e o seu ambiente. Visão que pode ser entendida como o ato de olhar ou observar. $\mathrm{O}$ autor propõe que avancemos da noção da visão como modo de especulação para a noção de visão como modo de participação e, finalmente, para visão como modo de ser. Como projeto de uma antropologia dos sentidos, considera fundamental que se restitua aos mundos virtuais do sentido as praticidades de nossa maneira sensória de perceber o mundo. São essas praticidades que capturam na análise das imagens produzidas por fotógrafos cegos. Observando as diferenças nas condições de cegueira e as distintas imagens que os fotógrafos cegos produzem a partir de uma tal variabilidade, a cegueira nos revela que a praticidade e o movimento estão por trás de toda visão, ou de toda forma de perceber e estar no mundo.

Como vimos, as convenções de avaliação e ensino da fotografia costumam fixar o olhar. O lugar de onde se vê é padronizado por regras de ordenamento que abrangem alguns movimentos e não outros. O próprio uso convencional do equipamento fotográfi$\mathrm{Co}$, que deve ser segurado em frente ao rosto, na altura dos olhos, estimula a fixidez do olhar e não o movimento. A maior parte das fotografias é igual porque as pessoas estão atadas a regras e convenções que geram sempre "mais do mesmo". Se é a atividade, o movimento e a atenção que constitui a visão (de qualquer pessoa), é também a criatividade no movimento e na direção de sua atenção que guiará o resultado que congelará em uma foto. Ultrapassar o universo das regras e das convenções e gerar uma foto, ou uma visão, inusitada - "o diferente" - depende justamente do movimento, da posição, do engajamento, da postura, das oscilações corporais feitas pelo fotógrafo, cego ou não cego, no ato de fotografar. Daquilo que ele efetivamente consegue perceber em uma cena, que provocará variações - diferenças - na imagem captada. 
Noë e O'Regan (2002) classificam a visão como uma atividade que depende de uma série mais ampla de outras capacidades, como o movimento corporal e a direção da atenção, por um lado, mas também capacidade de fala e pensamento racional, por outro. As pessoas se tornam conscientes daquilo que veem na medida em que controlam a informação com o propósito de guiar a ação e o pensamento. Ver é uma atividade exploratória mediada pelo domínio de contingências sensório-motoras. É uma atividade que se baseia na habilidade de explorar o ambiente. A experiência visual não é algo que acontece nos indivíduos, mas sim algo que eles fazem. É a partir do entendimento da visão como atividade que podemos apreciar as habilidades visuais que os fotógrafos cegos apresentados manejam. Embora fisiologicamente não enxerguem, seu movimento corporal e sua atenção são direcionados por referenciais sensoriais que guiarão o processo de captação e o registro da imagem visual. Do mesmo modo, utilizam a fala e o pensamento como guias para a ação de fotografar, ampliando a consciência imagética.

No centro de abordagens que privilegiam a visão como formato mais apropriado para o conhecimento do mundo, Ingold (2008) identifica a teoria representacionista, que considera que as pessoas partiriam do material bruto de uma sensação corpórea para construir uma imagem interna de como é o mundo "lá fora". Tal teoria se sustenta a partir de uma distinção fundamental entre uma dimensão física - o registro de sensações pelo corpo e pelo cérebro - e uma dimensão cultural - a construção de representações na mente. Uma concepção de como o conhecimento e o pensamento se constroem teria levado à redução da visão a uma modalidade sensória especializada na apropriação e manipulação de um mundo objetificado. A fonte da redução estaria justamente na equalização entre visão e visualização - a formação interna, na mente, de imagens ou representações de um mundo externo.

Em vez de considerar que as formas das coisas estejam idealmente prefiguradas no mundo, sejam impostas sobre a matéria e representadas na mente, Ingold (2015) propõe que as formas 
surgem por meio de um engajamento de forças e materiais em um mundo que está perpetuamente em construção pelas atividades de seus habitantes. Perceber, tanto quanto imaginar, é participar de dentro no perpétuo autofazer do mundo, é se juntar a um mundo em que as coisas não tanto existem, mas ocorrem, cada uma em sua própria trajetória de devir. Para o autor, se a imaginação é um trabalho da mente, é de uma mente que se mistura livremente com o mundo ao longo de múltiplas linhas de participação sensorial. Na vida da imaginação, o mundo é um feixe de trajetórias que se enredam e desenredam aqui e ali.

Acredito que é o trabalho incessante do engajamento perceptivo e sensorial da imaginação que as fotografias geradas por fotógrafos cegos nos revela. Tanto nas fotografias auditivas e nas imagens táteis do segundo grupo quanto no processo criativo do terceiro grupo, podemos identificar como característica marcante o uso de uma câmera subjetiva que provoca a sensação, para o observador, de que ele está dentro da cena, participando daquilo que o fotógrafo estava vivenciando no exato momento em que tirou a foto. No caso dessas imagens, no entanto, o que é visto pelo observador não é exatamente um mundo de formas objetificadas, mas algo que aciona outros modos de vivenciar e representar uma experiência, que transborda da visualidade da cena: o toque, a sensação da água ou do vento, as particularidades sonoras, a relação de luz e contraste.

A fisiologia da cegueira também importa: se é congênita ou adquirida, se ainda há memória visual, o uso que se faz dessa memória, se há percepção de contraste ou vulto e a relação com os traços de luz ou visualidade na percepção de si e do mundo. Como lembra Toren (2012), a história não é externa ao que é humano, pelo contrário, tudo em nós - tanto características fisiológicas quanto aquilo que fazemos ou pensamos - manifesta o processo histórico que vivemos. Para a autora, somos produto de uma transformação contínua de um passado vivido que manifestamos e projetamos, de uma só vez, no presente. A história da relação en- 
tre visão e cegueira de cada um está impressa em seu corpo vivo, atualizando-se também em suas imagens.

Se ver é um modo de atividade, não existe uma característica intrínseca ou propriedade única que seja definidora da experiência. Tal forma de compreender a visão, não como algo que acontece dentro do cérebro e nem como uma representação interna detalhada do ambiente externo, mas sim como atividade que depende do engajamento, da atenção, do histórico de vivências e dos padrões de movimento de um sujeito - além do próprio contexto cultural (MACDOUGALL, 2006) -, permite descrever a cegueira não como incapacidade de ver, mas sim como um modo próprio de produção de imagens.

As ações de pensamento, criação e conhecimento ainda são hegemonicamente consideradas fenômenos imateriais, descolados do corpo e de seus contextos específicos (GREINER, 2010). Entretanto, há todo um conjunto de conhecimentos que vem se afirmando em diferentes domínios de investigação que contesta tal posição, considerando a cognição como inseparável da ação de um corpo inteiro em um ambiente. O conhecimento depende de um estar no mundo que é inerente ao nosso corpo, língua, ou história social - em resumo, a nossa corporificação. A cognição, portanto, depende dos tipos de experiências que advém do fato de se ter um corpo, com suas diferentes capacidades sensório-motoras. Para uma abordagem enativa (MATURANA, VARELA, 1995), as imagens - ou as representações - que fazemos, emergem de situações específicas, não se concentram exclusivamente no cérebro e são fruto da atividade de um ser como um todo. Kastrup, Carijó e Almeida (2009) destacam a dimensão ontológica da ação na teoria de Maturana e Varela, já que as ações configuram, num movimento de co-engendramento, tanto o sistema cognitivo quanto o domínio cognitivo. Recorrendo a este modelo, os autores defendem que o cego deve ser entendido como alguém que porta um corpo cognitivo próprio: 
A visão é um tipo de prática cognitiva que responde pela autoprodução de um sistema cognitivo cuja plataforma é visual, engendrando, ao mesmo tempo, um mundo visual. Da mesma maneira, práticas cognitivas táteis produzem como resultado um sistema dotado de uma plataforma cognitiva tátil e de um mundo eminentemente tátil. [...] A cegueira traz afecções características e conexões peculiares, dificuldades e capacidades, deficiências e potências, que configuram um corpo e um modo de perceber, de se deslocar, de se comunicar e de viver, definindo também um domínio cognitivo e configurando um mundo. (KASTRUP, CARIJÓ, ALMEIDA, 2009, p. 115)

Aumont (1993) chama a atenção para a faculdade de projeção presente nos esquemas perceptivos do espectador que observa uma imagem. Ela supre o não representado, ou as lacunas de representação, com base em um acervo visual prévio, dados icônicos precedentemente encontrados e armazenados na memória sob forma esquemática. Como reconhecer uma imagem gerada por um fotógrafo cego quando o que motivou o registro da cena não foi o seu aspecto visual? O que devemos procurar quando olhamos tal imagem? É claro que podemos reconhecer o mundo visual presente na foto, mas não são apenas essas informações que estão ali dispostas para serem apreciadas. Com a fotografia de cegos, se apenas tentarmos reconhecer suas fotos por meio dos esquemas perceptivos visuais prévios o que deixaremos de ver ali são essencialmente as suas diferenças: os aspectos singulares da visualidade de quem fotografa para ver, de quem fotografa suas visualizações internas ou mesmo de quem, através da fotografia, registra imagens não visuais. Para apreciá-las em sua singularidade e fazê-las existir em sua diferença o espectador deverá suspender sua tendência projetiva.

Nas imagens apresentadas encontramos ao menos três formas distintas de visualização, que estão intrinsecamente relacionadas às praticidades e aos modos como os corpos cegos se engajam ativamente com o mundo e as outras pessoas, bem como à trajetória pessoal de cegueira. A primeira resulta da combinação 
do histórico de visualidade prévio à cegueira - um acervo mnêmico visual - que, ao ser atualizado em novos arranjos mentais, gera uma representação externa - uma fotografia - que será a mimesis de uma imagem internamente visualizada, embora nunca vista. A segunda se dá a partir do modo sensitivo próprio de abertura ao mundo que se constrói pela não visualidade, gerando imagens que, esteticamente, evocam as atmosferas perceptivas vividas em uma cena - sonoridade, toque, cheiro, sensações. A terceira forma de visualização é própria aos ciborgues que somos, fruto da combinação máquina e organismo. As imagens geradas nesta última forma são híbridos que nascem da fusão de olhos com funcionamento fisiológico específico, com a amplificação e potencialização dessa limitada visualidade pelos aparatos tecnológicos.

MacDougall (2006) sugere que o significado é produzido por nossos corpos inteiros, não só pelo pensamento consciente. Vemos com o nosso corpo e qualquer imagem que façamos carrega a marca de nosso ser. Os significados culturais guiam a percepção, mas a percepção também pode reconfigurar significados. O autor entende a produção de filmes como um processo de olhar com certo interesse, com certa vontade. Simplesmente olhar, olhar cuidadosamente, com atenção e livre de distrações, seria uma forma de conhecer diferente de pensar. Partindo de exemplos de câmeras que veem, mas podem ser cegas - câmeras de vigilância, filmagens panorâmicas de paisagens, jovens cineastas em fase inicial de aprendizado -, o autor distingue "ver" de "olhar", a partir do grau de atenção que se dedica a uma imagem. Com as imagens de fotógrafos cegos aqui trabalhadas e o esforço de reterritorialização da visão em um corpo que não pode ser separado de sua história e dos seus modos próprios de abertura e engajamento no mundo, podemos admitir que, assim como seria possível ver sem olhar, a cegueira nos ensina ser também possível olhar sem ver. 


\section{Referências}

AUMONT, Jacques. A imagem. Campinas: Papirus, 1993.

BARTHES, Roland. A Câmara clara. Rio de Janeiro: Nova Fronteira, 2008.

BAVCAR, Evgen. A luz e o cego. In: NOVAIS, A. (org.).

Artepensamento. São Paulo: Companhia das Letras, 1994.

BAVCAR, Evgen. O corpo, espelho partido da história. In: NOVAIS, A (org.). $O$ homem Máquina: a ciência manipula o corpo. São Paulo: Companhia das Letras, 2003.

BAZIN, André. Ontologia da imagem fotográfica. In: XAVIER, I. (org.). A experiência do cinema. Rio de Janeiro: edições Graal, 1991.

BECKER, Howard. Los mundos del arte: sociología del trabajo artístico. Bernal: Universidad Nacional de Quilmes, 2008.

BENJAMIN, Walter. A obra de arte na época de suas técnicas de reprodução. In: A ideia do cinema. Rio de Janeiro: Civilização Brasileira, 1975.

BOHME, Gernot. Atmosphere as the Fundamental Concept of a New Aesthetics. In: Thesis Eleven, v. 36, n. 1, p.113-126, 1993.

CLARK, Andy.Natural-Born Cyborg: Minds, Technologies, and the Future of Human Intelligence. Oxford: University Press, 2003.

CLARK, Andy; CHALMERS, David J. "The Extended Mind". Analysis, p.10-23, 1998.

CRARY, Jonathan. Modernizing vision. In: FOSTER, H. Vision and Visuality: discussions in contemporary culture. New York: Dia Art Foundation, 1999. 
CRARY, Jonathan. Técnicas do Observador. Rio de Janeiro: Contraponto, 2012.

FABIAN, Johanes. Time and the Other. New York: Columbia University Press, 2014.

GAGNEBIN, Jeanne-Marie. Do conceito de mímesis no pensamento de Adorno e Walter Benjamin. In: Perspectivas, São Paulo, n. 16, p. 67-86, 1993.

GARLAND-THOMSON, Rosemarie. Staring: how we look. Oxford: Oxford University Press, 2009.

GOFFMAN, Erving. Estigma. Rio de Janeiro: Zahar, 1975.

GOFFMAN, Erving. A representação do eu na vida cotidiana. Petrópolis: Vozes, 1996.

GREINER, Christine. 0 corpo em crise. São Paulo: Annablume, 2010.

HARAWAY, Donna. A Cyborg Manifesto. In: HARAWAY, D. Simians, Cyborgs and Women. New York: Routledge, 1991.

HATWELL, Yvete. “Le développement perceptivo-moteur de l'enfant aveugle". Enfance, vol. 55, p. 88-94, 2003.

HUYSSEN, Andreas. Monumentos e memória do holocausto numa idade da mídia. In: HUYSSEN, A. Seduzidos pela memória. Rio de Janeiro: Aeroplano, 2000.

INGOLD, Tim. Pare, olhe, escute. PONTOURBE, v. 3, n. 2, jul, p. $1-45,2008$.

INGOLD, Tim. “Da transmissão de representações à educação da atenção". Educação, v. 33, n. 1, p. 6-25, 2010.

INGOLD, Tim. Estar vivo. Petrópolis: Vozes, 2015. 
JAY, Martin. Scopic regimes of modernity. Vision and visuality (2), p. 3-27, 1999.

KULCSÁR, João. "Fotografias feitas por deficientes visuais, por que não?" Resgate - Rev. Interdiscip. Cult., Campinas, v. 26, n. 2 [36], p. 131-148, jul./dez. 2018 KASTRUP, Virginia; CARIJÓ, Felipe. H.; ALMEIDA, Maria Clara. A abordagem da enação no campo da deficiência visual. Informática na educação: teoria e prática, v. 12, n. 2, p.114122, 2009.

MACDOUGALL, David. The corporeal image. Princeton University Press, 2006.

MARTINS, Bruno Sena. "E se eu fosse cego?" Narrativas silenciadas da deficiência. Porto: edições Afrontamento, 2006.

MATURANA, Humberto; VARELA, Francisco. A árvore do conhecimento. Campinas: Editorial Psy, 1995.

MAUSS, Marcel. As técnicas do corpo. In: Sociologia e Antropologia. São Paulo: Cosac \& Naify, 2003.

MCCULLOH, David. Curatorial. Sight Unseen: International Photography by Blind Artists. Exhibition on view from may 2 to august 29 at the UCR/California Museum of Photography. University of California, 2009.

MERLEAU-PONTY, Maurice. A dúvida de Cézanne. In: MERLEAUPONTY, M. O olho e o espírito. São Paulo: Cosac \& Naif, 2004. MONDZAIN, Marie-José. What does seeing an image means? Journal of visual culture, v. I 9, n. 3, p. 307-315, 2010. MOREIRA, Luciane. Cegueira sob a visão médica. In: MOSQUERA, C. (org.) Deficiência visual: do currículo aos processos de reabilitação. Curitiba: Editora do Chain: 2014. p. 67-92. 
NOË, Alva; O'REGAN, J. Kevin. On the brain-basis of visual consciousness: a sensorimotor account. In: NOË, A. \& THOMPSON, E. (orgs.). Vision and Mind. London: MIT press: 2002.

RODRIGUES, Maria Rita C. Mosaico no tempo: uma interação entre corpo, cegueira e baixa-visão. Rio de Janeiro: Instituto Benjamin Constant, 2014.

SIMMEL, Georg. Rembrandt: Ensayo de filosofía del arte. Valencia: Soler, 1996.

SOULAGES, François. A fotograficidade: como reflexão sobre as imagens (de imagens). Revista Farol, n. 18, p. 142-151, 2017.

TOREN, Chirstina. Antropologia e psicologia. Revista Brasileira de Ciências Sociais, v. 27, n. 80, p. 21-36, 2012.

VERINE, Bertrand. Não podemos ver, não devemos tocar: quais as repercussões dessa máxima no discurso das pessoas cegas? Revista Benjamin Constant, v. 19, p. 6-19, out. 2013.

VON DER WEID, Olivia. Visual é só um dos suportes do sonho: práticas e conhecimentos de vidas com cegueira. Tese (doutorado em antropologia cultural). Rio de Janeiro: PPGSA/ UFRJ, 2014. VON DER WEID, Olivia. "A janela da expressão": reflexões sobre corpo, movimento e gesto nas relações entre visão e cegueira. Anuário Antropológico, v. 44, n. 1, p. 159-186, 2019.

WOODWARD, Kathryn. Identidade e diferença: uma introdução teórica e conceitual. In: SILVA, T. T. (org.). Identidade e Diferença. Petrópolis: Vozes, 2014. 